\title{
MORISCOS PENINSULARES, MOROS FILIPINOS Y EL ISLAM EN EL EXTREMO ORIENTAL DEL IMPERIO ESPAÑOL: ESTUDIO Y EDICIÓN DE LA SEGUNDA CARTA PARA LA S.C.M.R. ACERCA DE LOS MAHOMETANOS DE LAS PHILIPINAS DE MELCHOR DE ÁVALOS (1585)
}

Francisco Franco Sánchez e Isaac Donoso Jiménez*

Una de las principales líneas de investigación en que Míkel de Epalza trabajó fue la que tenía que ver con el estudio de los moriscos, cuyos descendientes e historia conoció y llegó a estimar en su estancia en tierras tunecinas. Sus aportaciones más notables tienen que ver con la comprensión de este colectivo social en su condición de musulmanes ocultos, cultos y con culto, estudiando sus vicisitudes religiosas y sociales, habiendo sido su última contribución el excelente y exhaustivo estudio sobre la lengua hispana hablada por los moriscos tunecinos ${ }^{1}$.

Entre sus estudios sobre el islam de los moriscos no faltan aproximaciones a las vías de evangelización de los mismos y comparaciones con la evangelización de los indios americanos, de las que surgieron evidentes paralelos ${ }^{2}$. En

* Universidad de Alicante.

1. M. de Epalza y A.-H. SlAmA-GAFsi, El español hablado en Túnez por los moriscos o andalusies y sus descendientes (siglos XVII-XVIII): material léxico y onomástico documentado, siglos XVII-XXI, prefacio de Luis F. Bernabé Pons, prólogo de Alfonso de la Serna, Valencia, 2010.

2. Míkel no trató específicamente este tema, aunque no dejó de aludir al mismo en algunos pasajes de su ya canónica obra Los moriscos antes y después de la expulsión, Madrid, 1992, y recuerdo cómo animó a la estudiante de doctorado Concepción Agüero para que hiciera un paralelo entre los catecismos dedicados a la conversión de los moriscos y los dedicados a la conversión de los indios americanos, que al final esta trabajó en su tesina. Robert Ricard fue el iniciador de una serie de estudios sobre la influencia de la experiencia obtenida en España 
esta línea de estudios queremos aportar un nuevo paralelo, que aunque aparentemente lejano es muy próximo, y que tiene que ver con la evangelización de los musulmanes que se encontraron los españoles en las lejanas Islas Filipinas.

En el repertorio de documentación del Archivo de Indias, publicado por Lewis Hanke relativo a los "derechos de España sobre las Indias y Filipinas" ${ }^{3}$, se halla un documento de extraordinario valor que habla de la evangelización de los musulmanes de Filipinas, el cual muestra claramente las posturas de cierta parte de la sociedad española más intransigente, y que presenta indudables paralelismos con la evangelización de los moriscos españoles. Se trata de Dos cartas y ale-

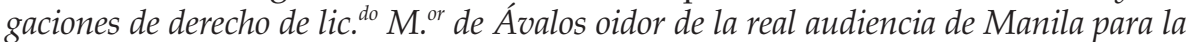
S.C.M.R. acerca de los mahometanos de las Philipinas y contra ellos. Realmente son dos auténticos memoriales, más que propiamente dos misivas epistolares como indica su título, compuestos por el licenciado Melchor de Ávalos y remitidos en fecha de 20 de junio de 1585 a la Sacra Cesárea Majestad Real, el rey Felipe II. La intención que tenían estas misivas en la política general hacia los musulmanes de Filipinas -y en extensión hacia la población autóctona del archipiélago- era crear un clima favorable para su conversión al cristianismo, lo mismo que había ocurrido con los mudéjares de las coronas de Castilla (1501 en el reino de Granada y 1502 en el resto de la Corona de Castilla) y de Aragón (1525).

Deseamos ofrecer el estudio de este documento en homenaje al maestro de arabistas, de islamólogos, historiadores, moriscólogos..., al maestro que tan-

con las misiones americanas y viceversa, «Indiens et Morisques. Notes sur quelques procédés d evangélisation", Journal de la Société des Américanistes de Paris, n. s., t. 18, 1926, pp. 350-357. Sobre este tema han profundizado más recientemente los libros de A. GARRIDO ARANDA, Moriscos e indios. Precedentes hispánicos de la evangelización en México, México, 1980; L. Resines, Catecismo del Sacromonte y Doctrina Cristiana de Fr. Pedro de Feria, conversión y evangelización de moriscos e indios, Madrid, 2002; Y. El Alaou, Jesuites, Morisques et Indiens. Étude comparative des méthodes d'évangélisation de la Compagnie de Jésus d'après les traités de José de Acosta (1588) et d'Ignacio de las Casas (1605-1607), Paris, 2006; L. CARDAILlaC, Indios y Cristianos. Cómo en México el Santiago español se hizo indio, México, 2007. Igualmente remitimos a los estudios de A. GARRIDO ARANDA, «El morisco y la inquisición novohispana (actitudes antiislámicas en la sociedad colonial», II Jornadas de Andalucía y América, Sevilla, 1984, vol. I, pp. 501-533; M. GARCÍA-ARENAL, «Moriscos e indios, para un estudio comparado de métodos de conquista y evangelización», Chronica Nova, 20, 1992, pp. 153-175, y «Moriscos and Indians, a Comparative Approach», The Middle East and Europe, Encounters and Exchanges, edited by G. Jan van der Gelder, ed. de Moor, Orientations, 1, 1992, pp. 39-55; J. SÁNCHEZ HERRERO, «El posible enfrentamiento entre Talavera y Cisneros en relación con la evangelización de los moros granadinos como paradigmático del enfrentamiento entre Motolinía y Las Casas en la evangelización de los indios americanos», El Reino de Granada y el Nuevo Mundo. Congreso Internacional de Historia de América, Granada, 1994, vol. I, pp. 567-577; B. SUÑE BLANCO, «Los moriscos de Granada y los indios de Yucatán, análisis comparativo de una política de aculturación», El reino de Granada y el nuevo mundo. Actas del V Congreso Internacional de Historia de América, Granada, 1992, Granada, 1994, vol. I, pp. 567-577.

3. L. HANKE, Cuerpo de documentos del siglo XVI. Sobre los derechos de España en las Indias y las Filipinas, descubiertos y anotados por Lewis Hanke, compilador Agustín Millares Carlo, México, 1943.

4. En efecto, Melchor de Ávalos parece responder a relaciones de sucesos previas en las que se delimita la extensión y penetración del mensaje islámico en el archipiélago filipino, especialmente la aparecida en 1572. Cfr. infra nota 25. 
tos temas trabajó, aparentemente, porque cuando se le conocía se evidenciaba que su perspectiva unificadora siempre fue la islamología, como disciplina y variable de investigación que aplicaba a muchos y diversos ámbitos de investigación, perspectiva novedosa y enriquecedora que en esta ocasión queremos honrar con este estudio.

\section{MELCHOR DE ÁvALOS Y SUS ESCRITOS}

El licenciado Melchor de Ávalos llegó a Manila el 26 de mayo de 1583 procedente $-\mathrm{y}$ tras haber vivido largo tiempo- de Nueva España, muriendo en dicha ciudad en $1590^{5}$. Llega para desempeñar el nuevo cargo de primer oidor de la recién establecida Audiencia.

La primera noticia que poseemos de él tiene que ver con la concesión de un solar por parte de la ciudad de México, el 3 de diciembre de $1563^{6}$. Allí sirvió como ayudante de la Inquisición durante once años. Por tiempo de diez o doce meses fue fiscal de la Audiencia y no deja de señalar que durante ese tiempo hizo más que había hecho su predecesor en veinte años. Tenemos noticia de que durante el pleito entre los herederos de Hernán Cortés actuó como asesor jurídico ${ }^{7}$, habiendo en total "gastado cuarenta años en continuos estudios, treinta de los cuales me han dado mucha experiencia en cuestiones de justicia y abogacía".

Esta larga experiencia jurídica contribuye a explicar el extraordinario número de citas que Ávalos hace en estas dos cartas-memoriales de mucha de la literatura jurídica, antigua y reciente, sobre lo que el derecho canónico tiene regulado referente al trato que se ha de dar a los musulmanes. Ya antes de salir de México, Ávalos había escrito al rey sobre esta cuestión, insistiendo en que se celebrara una junta especial para la tranquilidad de la real conciencia, y prometiendo escribir de nuevo sobre el asunto desde las islas.

La carta que acompañaba a las otras dos cartas-memoriales (auténticos tratados) que publicamos, fue enviada el 3 de julio de $1584^{8}$. Menciona la llegada y establecimiento de la Audiencia en Manila, se queja de que no logra obte-

5. En la introducción a la compilación documental, L. Hanke hace una presentación de cada documento. En la misma, esboza unos apuntes sobre Melchor de Ávalos y sus cartas, que retomamos en sus principales líneas argumentales, L. HANKE, op. cit., pp. XXIX-XXI.

6. Según recogen las Actas de cabildo de México, México, 1889-1916, vol. VII, p. 153.

7. Documentos inéditos relativos a Hernán Cortés y su familia, México, 1935, pp. 111, 113, 114.

8. En el prefacio al volumen VI de la monumental antología de traducciones de Blair \& Robertson se describe el texto de Ávalos con el siguiente juicio de valor, "containing some valuable information regarding matters in the islands, is a curious mixture of pedantry, bigotry, egotism, and vanity", en E.H. BLAIR y J.A. ROBERTSON, The Philippine Islands, Cleveland, 19031909, vol. VI, pp. 14-15. Sin entrar en la fidelidad o no de las traducciones, juicios de valor de 
ner el salario que se le debe, y relata los servicios que, según cree, le hacen merecedor de un mejor tratamiento. Pide instrucciones sobre lo que deberá hacerse con los musulmanes. mencionando el permiso dado anteriormente a Legazpi por el rey para esclavizar en ciertos casos a los musulmanes (mencionados como moros $)^{9}$, y también el ejemplo establecido por los soberanos de España y Portugal al expulsar o someter a los moriscos que habitaban en sus dominios. Ávalos desea también que el rey regule (reconsidere) la cuestión de la posesión de esclavos por los españoles, que se inclina a justificar; y que adopte medidas que impidan a los chinos adueñarse de todo el dinero que va a las Filipinas. Existe la mayor pobreza entre los soldados españoles, a los que no se paga; y Ávalos sugiere que se les envíe a hacer nuevas conquistas para que puedan sostenerse por sí mismos. La guarnición española de las Molucas está amenazada por el rey indígena de Ternate, y debe enviarse en su ayuda una gruesa fuerza de tropas. Surge entre los oficiales españoles una disputa sobre la designación de jefe para esta expedición, que Âvalos propone solucionar yendo él mismo, satisfaciendo así a todos los capitanes descontentos, según informa

esta naturaleza han puesto de relieve la manipulación historiográfica de la empresa bibliográfica norteamericana a comienzos de la dominación estadounidense en Filipinas. Véase G. CANO, «Blair and Robertson's The Philippine Islands, 1493-1898, Scholarship or Imperial Propaganda?», Philippine Studies, 56, núm. 1, 2008, pp. 4-36.

9. Miguel López de Legazpi, en su Memoria de 1567 al rey de España Felipe II, estipula diferentes aspectos de la colonización filipina. Una de las cuestiones señaladas por Legazpi fue la posibilidad o no de esclavizar los musulmanes en el archipiélago, dado que resultaban un obstáculo tanto para la cristianización como especialmente para el control del comercio y la política en la región, «Otro sí, piden y suplican a su Majestad por cuanto en estos reinos e señoríos suyos tratan moros y llevan el oro que en estas islas ay y los demás frutos, como es cera, canela y otras cosas que hasta ahora no se han alcanzado a entender; y por cuanto estorban y procuran estorbar la contratación de los naturales con nosotros y les predican la seta mahometana e no da lugar a que en ella se cultive el santo evangelio, que los tales moros sean esclavos e pierdan las haciendas que se les tomaren», en P. HidALGO NuCHERA, La recta administración. Primeros tiempos de la colonización hispana en Filipinas: la situación de la población nativa, Madrid, 2001, p. 89. Cita de la Memoria de lo que se envió a pedir a su Majestad de merced, franquezas e libertades por los capitanes conquistadores oficiales que al presente en esta jornada e nuevo descubrimiento le sirven en las Yslas Felipinas, governador Miguel López de Legazpi, 1567 en Cebú; texto editado igualmente en Colección de documentos inéditos relativos al descubrimiento, conquista y organización de las antiguas posesiones españolas de ultramar, Madrid, 1887, tomo 3, II, pp. 321-322. La respuesta del rey fue que, a menos que musulmanes provenientes de fuera del archipiélago apareciesen para predicar o hiciesen una declaración de guerra abierta, ningún musulmán de los llamados moros dentro de las islas podrá ser hecho bajo ningún concepto esclavo. Es más, se debería promover una política de atracción e incorporación dentro de las nuevas estructuras del Estado que se quería establecer. El texto fue glosado por el propio Ávalos, “También se nos ha pedido por vuestra parte [Legazpi], que atento a que hay en esa tierra islas de moros y ellos vienen y tratan y contratan, los cuales impiden la predicación del Santo Evangelio y os inquietan, os damos licencia a hacer a tales moros esclavos, y tomarles sus haciendas, y estaréis advertidos que si los tales moros son de su nación y naturaleza moros, y vinieran a dogmatizar su secta mahomética o a hacer guerra a vosotros o a los indios que están a nos sujetos y a vuestro real servicio, los podéis hacer esclavos; más a los que fueren indios y hubieren tomado la secta de Mahoma, no los haréis esclavos por ninguna vía ni manera que sea, sino procuraréis de los convertir y persuadir por lícitos y buenos modos a nuestra santa fe católica". 
a su real correspondiente. Desea que el rey le conceda autoridad para castigar a los chinos por sus prácticas viciosas, y piensa que los frailes deberían convertir y bautizar a estos paganos con más rapidez de lo que lo están haciendo.

En esta carta, que remite con las dos cartas-memoriales que reproducimos en el Apéndice, Ávalos informa al rey que después de la preparación de su primera carta-memorial ciertos franciscanos y agustinos habían afirmado que tanto la Audiencia como los eclesiásticos estaban faltos de la suficiente jurisdicción para castigar la idolatría de los naturales. Esta opinión le había ofendido de tal modo que había compuesto en seguida el segundo tratado, junto con una colección de treinta y seis "Ordenanzas contra idolatría y sodoma". Afirma que estas ordenanzas habían sido presentadas a la Audiencia, pero no se habían publicado, motivo por el que Ávalos insiste enérgicamente para que el rey lo haga, y que sean "publicadas con trompetas y voz de pregonero y mediante dos intérpretes de cada nación o lugar" ${ }^{\prime 10}$.

La fuerza del sentimiento latente contra los musulmanes en las Filipinas puede verse claramente en estos dos tratados eruditos de Ávalos. Aunque Ávalos las denomine "cartas", su extensión, estructuración en epígrafes temáticos, así como lo prolijo de sus exposiciones y abundantísimas citas, que remiten a los seis textos básicos del derecho canónico ${ }^{11}$, así como a los evangelios y algún decreto más (como auctoritas jurídicas y religiosas en las que busca fundamentar sólidamente sus argumentos), convierten a estos dos documentos en dos auténticos tratados, o memoriales, alejándolos del género meramente epistolar. No sólo cita a Aristóteles, Santo Tomás, San Agustín, Covarrubias, Gregorio López, el Hostiense, Susannis, Navarro, Vázquez Menchaca, Vitoria, Palacios Rubios, Alfonso de Castro, Domingo de Soto, Las Casas, Simancas, Lucas de Peña y una multitud de otras autoridades, sino que también habría leído las obras recientemente publicadas de Tomás de Mercado ${ }^{12}$ y Juan Focher ${ }^{13}$.

Los dos tratados se refieren exclusivamente a la cuestión musulmana, aunque se circunscriben al problema específico y peculiar de las Islas Filipinas. En las Indias eran familiares a los españoles sus naturales, encuadrados dentro de la condición de "infieles", pero ¿qué actitud deberían tomar hacia estos representantes del antiguo enemigo de España que se encontraban en gran número en las Filipinas? Por ello recupera y compila la normativa represora que se había ido ge-

10. Cartas de Ayala sobre moros, idolatría etc. Ordenanzas, Archivo General de Indias, Sevilla, Filipinas, 18A, R.3, N.19. Las Ordenanzas se encuentran con una carta fechada el 24 de junio de 1588.

11. Esto es, las Quinque compilationes antiquæ, más la sexta colección los Decretales Gregorii IX, también denominados a veces Compilatio sexta, Collectio seu liber extra, y vagantes extra. Ver explicaciones más detalladas en notas del Apéndice Documental.

12. Tomás de Mercado, Tratos y contratos de mercaderes, Salamanca, 1569.

13. I. FOCHER, Itinerarium catholicum proficiscentium ad infideles convertendos..., Sevilla, 1574, texto latino con versión castellana, introducción y notas de A. EGUILUZ, O.F.M., Madrid, 1960. El original del franciscano francés J. Focher fue completado y precisado, "por mandato del General de la Orden", por Fr. Diego Valadés tras la muerte de su autor. 
nerando con el tiempo respecto a los musulmanes en tierras europeas y en general, siendo por ello un tratado de enorme interés jurídico y en el ámbito de historia del derecho y también de las mentalidades. Se nos revela que Melchor de Ávalos es consciente de los diversos planteamientos políticos (Junta de Valladolid; controversia Las Casas-Sepúlveda de 1550-1551; el derecho internacional público de Francisco de Vitoria y la Escuela de Salamanca, etc.) y jurídicos (Requerimiento Notificador de 1513; Ordenanzas sobre el buen tratamiento de los indios de 1526; Leyes Nuevas de 1542, etc.) que a lo largo del siglo XVI tienen lugar en la interpretación de "el Otro". Así pues, el texto es de capital importancia, pues ya no se trata tan sólo de "el Otro" como "indio", sino como "moro", precisamente en el mismo momento es que se estaba discutiendo la cuestión morisca.

Ávalos comienza probando la validez de la concesión papal, y pasa luego a la duda sencilla y principal de si puede permitirse a los musulmanes vivir bajo la jurisdicción de reyes cristianos sin que los monarcas incurran en censura y excomunión a causa de ello. La respuesta, ilustrada con una multitud de citas, es que no. El cargo principal de ambos tratados es "que todos los musulmanes son enemigos de la iglesia y de España" y "que los españoles tienen el poder, o mejor el deber, de hacerles la guerra para castigarlos por sus costumbres idolátricas" ${ }^{\prime 14}$.

Para ilustrar la antigua enemistad entre cristianos y moros, Ávalos se refiere a aquel curioso episodio de 1505, cuando el sultán de Egipto envió una carta en términos violentos al papa Julio II, protestando de la conversión forzada de los moros e informando con indignación al papa de que los cristianos no eran nunca forzados a convertirse en moros. Se invocaba la autoridad del papa Clemente $\mathrm{V}$ porque había declarado, con aprobación de la junta de Viena, que ningún príncipe católico debía permitir que un musulmán viviera bajo su jurisdicción. Ávalos advertía a Felipe II que algunos de los turcos vencidos en Lepanto habían marchado a Oriente para predicar su doctrina y dar consejo a sus compañeros infieles en las guerras hechas contra la intervención europea en el

14. Los españoles manifestaron la misma actitud hacia los musulmanes en el siglo XVI que la general de Europa en la Edad Media. Como ha mostrado D.C. MunRo se sacó mucho partido de su supuesta idolatría, sus costumbres matrimoniales y su propagación del islam por la espada, «The Western attitude toward Islam during the Crusades», Speculum, VI, 1931, pp. 329313. Hasta la publicación de Th. W. ARNOLD, The Preaching of Islam, Westminster, 1896, estuvieron difundidas muchas opiniones erróneas referentes al uso de la fuerza en las conversiones islámicas, y aún hasta de las conquistas de sus países, J. TOLAN, «"Cel Sarrazins me semblet mult hérite". L'hétérodoxie de l'autre comme justification de conquête (XIe-XIIIe siècles)», Actes des congrès de la Société des historiens médiévistes de l'enseignement supérieur public. 33e congrès, Madrid, 2002, pp. 65-74. Vasta y compleja es la bibliografía referente al imaginario cristiano sobre el islam, así como sobre la polémica cristiano-islámica; remitimos a los libros de Jean FLORI, L'Islam et la fin des temps. L'interprétation prophétique des invasions musulmanes dans la chrétienté médiévale (VII-XIII siècle), París, 2007 (trad. esp. El islam y el fin de los tiempos. La interpretación profética de las invasiones musulmanas en la Cristiandad medieval, Madrid, 2010), pero especialmente al trabajo de J.V. Tolan, Sarracens. Islam in the Medieval European Imagination, Columbia, 2002 (trad. esp. Sarracenos. El Islam en la imaginación medieval europea, Valencia, 2007). 
sudeste asiático ${ }^{15}$. Los españoles deben someter "estos musulmanes para que vivan de acuerdo con la razón”, continuaba Ávalos, y recordaba a Felipe II que los romanos habían justificado sus conquistas análogamente. Los escritores que se oponían a la opinión del Hostiense de la plenitud del poder papal "sólo creaban confusión" y debían de ser llevados ante la Inquisición como herejes. Sin embargo, aun sin una bula papal, España tenía derecho a conquistar las Indias y a predicar la fe. Porque, como Ávalos aseguraba: "sin la dicha bula, y aunque no se hubiera hecho esta concesión para la casa de Castilla, pudiera V.M. cristianísimamente enviar por todo el mundo a la predicación y conversión de estos infieles y paganos, y compadeciéndose de ellos, alzar las fuerzas y librarlos de las tiranías del demonio y de sus malaventurados tiranos reyes, y defender los oprimidos y darles lumbre de fe cristiana, que ésta es la más propia virtud de los reyes católicos, libertar de los calumniantes a los que poco pueden y saben, y obra piadosísima"16.

El primer tratado fue compuesto a causa de la controversia que surgió entre el gobernador Sande y los eclesiásticos en la primera mitad de 1585, cuando el gobernador quemó la mezquita en Borneo ${ }^{17}$. Después de detallar la historia remota del conflicto entre la cristiandad y el islam, incluyendo una referencia a la predicación de Santo Tomás en la India, Ávalos declara que todos los musulmanes deberían ser castigados por sus "iniquidades y blasfemias y herejías". Al concluir la primera carta plantea dos cuestiones: " ¿No debieran los musulmanes ser obligados a pagar diezmos a la iglesia?”, “ ¿No debieran los musulmanes ser obligados a satisfacer el doble del tributo pagado por los gentiles ordinarios?"18.

El segundo tratado, fechado el mismo día que el primero, según palabras del propio Ávalos, fue escrito para resolver las nuevas dudas originadas por el obispo Domingo de Salazar y ciertos otros frailes, quienes habían afirmado que ni la audiencia ni el papa tenían jurisdicción sobre los infieles hasta que estuvieran bautizados. Ávalos acusa a los eclesiásticos de negar la autoridad del papa y para combatir los argumentos de los eclesiásticos presenta referencias bíblicas, de los canonistas, del Hostiense, Navarro, Simancas, Soto, Alfonso de Castro, Santo Tomás, Focher y otros muchos autores sabios. Increpa a aquellos frailes que decían que aunque vieran a los infieles adorando al demonio no intervendrían para castigarlos, lo cual encuentra "cosa cierto a mi parecer muy

15. Véanse los detalles sobre este tema en la Tesis doctoral de I. DonOso sobre El islam en Filipinas (ss. X-XIX), defendida el 6 de junio de 2011 en la Universidad de Alicante.

16. Primera carta-tratado, $\S 17$.

17. En este sentido, el texto de Ávalos es capital para entender la intrahistoria de la incipiente islamización en la bahía de Manila y la conexión existente con Brunéi, ya que ofrece datos en primera persona de informaciones que otras fuentes reflejan desde la distancia. Dada la trascendencia y valor de los datos que Ávalos transmite en relación a este tema, lo tratamos extensamente en otro lugar; véase Isaac DONOSO, «Manila y la empresa imperial del Sultanato de Brunéi en el siglo XVI», en Revista Española del Pacífico, Madrid (en prensa).

18. Primera carta-tratado, $\S 31$. 
áspera y escandalosa"19. Ávalos concede mucha confianza a las palabras de Gregorio López, afirma que San Pablo no negó el poder de la iglesia para juzgar infieles, y cita varios ejemplos de papas que los castigaron. No sólo pueden ser los infieles castigados, sino que deben imponérseles mayores tributos que a los fieles "para que se apresten a creer lo bueno" ${ }^{20}$.

En conclusión dice: "Con lo dicho queda resolutamente muy bien fundado que V.M. puede y su real audiencia y ministros podemos juzgar, punir y castigar los infieles, idólatras y peccantes adversus legem rationis naturalis, aunque vivan apartados de los nuevamente bautizados y aunque no les den escándalo los infieles y vivan en otras islas, pues siendo vasallos de tan católico y religioso príncipe, no se les pueden ni deben consentir idolatrías"21.

La última información relativa a este voluminoso y vehemente escritor sobre la cuestión de los musulmanes es de 1589, y en ella se informaba al rey de que Ávalos sufría muchos achaques y dolencias. Su muerte fue notificada en una carta de 20 de junio de 1590.

\section{La postura de Melchor de Ávalos ante LOS MUSULMANES DE FILIPINAS}

El proceso de institucionalización política que el islam estaba adquiriendo en el archipiélago filipino, con la creación del sultanado de Sulú a comienzos del siglo XV, el de Mindanao poco después, y el liderazgo de familias borneas en la bahía de Manila, hacían que el islam no sólo fuera competencia para los objetivos españoles, sino también una evidente oposición ${ }^{22}$. Es por ello que

19. Segunda carta-tratado, $\S 12$.

20. Ibid., $\S 19$.

21. Ibid., § 21 .

22. Una aproximación al proceso de islamización del archipiélago filipino en C.A. MAJUl, Muslims in the Philippines, Quezon City, 1999; C.A. ABUBAKAR, «Islamization of Southern Philippines, An Overview», en F. LANDA JocANo (ed.), Filipino Muslims, Their Social Institutions and Cultural Achievements, Quezon City, 1983, pp. 6-13; Id., «The Advent and Growth of Islam in the Philippines», en K.S. NATHAN y M. HASHIM KAMALI (eds.), Islam in Southeast Asia. Political, Social and Strategic Challenges for the $21^{\text {st }}$ Century, Singapur, 2005, pp. 45-63; A. IsIDRO y M. SABER (eds.), Muslim Philippines, Marawi, 1968; P. Gowing y R. McAmIs (eds.), The Muslim Filipino, Manila, 1974; P. GowING, Muslim Filipinos. Heritage and Horizon, Quezon City, 1979; A.P. SAKILI, Space and Identity, Expressions in the Culture, Arts and Society of the Muslims in the Philippines, Quezon City, 2003; D.M.O. Mastura, Muslim Filipino Experience. A Collection of Essays, Manila, 1984; S.K. TAN, Decolonization and Filipino Muslim Identity, Quezon City, 1989; J.R. RASUL, Struggle for identity. A Short History of the Filipino Muslims, Quezon City, 2003; y Gh. LOYRE-DE-HAUTECLOCQue, Evolution des Maranao, Des origines au XVIIIe siècle. Contribution à l histoire des musulmans philippins, París. 1989. Por otro lado, una contribución revolucionaria al estudio de las comunidades islámicas en el archipiélago filipino ha sido la del australiano James FRANCIS WARREN, cuya obra estudia los fenómenos demográficos y económicos aplicados a la región del 
parte de los autores españoles empiezan a contemplar a los musulmanes filipinos como se hacía a los musulmanes españoles, es decir, dentro de una misma campaña en la que el moro es "el Otro" (Maurus Africanus será el morisco español y Maurus Asiae el moro filipino, ambos alienados en su tierra): "assí que como de todos los otros sus rreynos, puede y debe V.M. echar y expeller a los moros de todas las Yslas Philipinas" ${ }^{23}$.

El texto de Ávalos posee un significativo alcance político para la primera comunidad española asentada en Asia. Como funcionario de la Audiencia de Manila, Ávalos ocupaba una posición de influencia, y sus informes dirigidos al rey buscaban arrogarse la representación del sentir general de la comunidad española en las Islas Filipinas. Pone en relación a los propios musulmanes granadinos y a los exiliados moriscos norteafricanos con el proceso de islamización en el sudeste asiático. Es más, afirma que derrotados en Lepanto se han encontrado después predicando el islam en la región y que, en consecuencia, los musulmanes filipinos "entran en la cuenta" como enemigos del rey de España.

Si bien puede suponerse que no haya motivos para que los hechos no sean ciertos, hay que tener en cuenta el interés propagandístico por parte de un sector de la administración española en Manila por magnificar la presencia islámica en el archipiélago. Quizás haya algo de verdad, pero resulta claro que Ávalos exagera la implantación del islam en el archipiélago filipino con el fin de legitimar la presencia española ( $v . g r$., es necesaria una cruzada que, como rey de una monarquía católica universal, Felipe II tiene que apoyar, más aún en un archipiélago que lleva su nombre $)^{24}$.

Los conflictos ideológicos españoles serán igualmente importados a Asia, y si el partido, o grupo de opinión, encabezado por Melchor de Ávalos se escandalizaba de la extensión del islam en la región y la necesidad de realizar una campaña agresiva -como en esos días se estaba debatiendo sobre el "problema morisco" que acabará con el decreto de expulsión de 1609-, otro sector español limitaba la existencia de los musulmanes en el archipiélago filipino, y especialmente la falacia conceptual que escondía la denominación de moros en la región de Manila:

Mar de Sulú con el fin de explicar las particularidades de una sociedad feudal para hacer frente a las exigencias del mundo globalizado llevado a la zona por el colonialismo europeo, The Sulu Zone, 1768-1898, The Dynamics of External Trade, Slavery, and Ethnicity in the Transformation of a Southeast Asian Maritime State, Singapur, 1981; Iranun and Balangingi. Globalization, Maritime Raiding and the Birth of Ethnicity, Singapur, 2002; y The Global Economy and the Sulu Zone, Connections, Commodities and Culture, Quezon City, 2000. Véase una nueva interpretación al proceso de islamización del archipiélago filipino, empleando las fuentes árabo-islámicas, en I. DONOSO, Islamic Far East. Ethnogenesis of Philippine Islam, Universidad de Filipinas (en prensa). Por el mismo autor se va a editar un estado de la cuestión del tema en More Islamic Than We Admit. The Easternmost Islamic Edge, Quezon City (en prensa).

23. Primera carta-tratado, $\S 6$.

24. Cfr. D. de LARIo (ed.), Re-shaping the World. Philip II of Spain and His Time, Quezon City, 2008. 
"Como digo, comen y beven hasta perder el juicio dende el menor hasta el mayor; en estos pueblos más cercanos de la mar no comen puerco algunos, la ocasión que an tomado de no lo comer, al principio dixe, cómo por tratar con los moros de Burney les an predicado alguna parte de la seta malvada de Mahoma, y que no coman puerco; y en esto hazen gran hincapié, é venido a preguntar á algunos destos por qué no lo comen, dizen: porque no lo saben; y si les preguntan quién fue Mahoma y qué es lo que manda su ley, dicen: que no lo saben, ni á Mahoma conocen, ny aun á su nombre tampoco, ny saben qué es su ley ni de qué manera. Verdad es que algunos que an estado en Burney, entienden alguna cosa, y saben leer algunas palabras del Alcorán; empero estos son muy pocos y tienen entre ellos opinión que el que no ubiere estado en Burney puede comer puerco, y esto yo se lo he oydo dezir á muchos dellos" 25 .

Esta corriente de escritores no ligados a la administración colonial postulará la superficialidad del islam en las Islas Filipinas y, en consecuencia, que los llamados moros filipinos no son ciertamente oposición, y tienen poco que ver con los "moros de Berbería". Así se dice en la que será la primera relación de sucesos española que se centre en el tema del islam y la población islamizada del archipiélago filipino, publicada en Manila, 1572, cuyo título es elocuente ya por sí solo.

El texto y el propio título de la relación escrita en 1572 (al año de establecerse la ciudad de Manila) informan elocuentemente de la dicotomía ideológica existente entre los primeros pobladores españoles del archipiélago. Parece claro, por lo tanto, que existe un elemento que se escapaba de las primeras relaciones enviadas al rey sobre los acontecimientos de la conquista y establecimiento de Filipinas. El hallazgo de población islámica o islamizada supondría un aliciente especial para parte de los primeros conquistadores, que verían en ello una facilidad añadida para justificar la usurpación de intereses y tomar servidumbre como esclavos. A través de la denominación de moros, la con-

25. Texto cuyo título describe elocuentemente su contenido, Relacion del descubrimiento y conquista de la isla de Luzón y Mindoro; de las cosas más señaladas que en ellas sucedieron, tratase breve y sumariamente de la manera que se conquistó y ganó de lo que hasta oy está ganado y conquistado en esta dicha isla; ansí mesmo, de la calidad de la gente della y su manera de vivir y las armas que usan y tiene, é fuertes que hazen para defenderse de los enemigos. Aseme ofreçido escribir esta rrelaçión por ser informado que se an escripto otras muchas, ymbiado á Nueva España, tratando de lo que en esta tierra a subcedido; las quales dicen que son muy fabulosas y profanas, diziendo que en esta tierra ay moros como los de Berberia, y que las fuerças armas que tienen es ni mas ni menos; y que pelean y se defienden como turcos. Los que tal han escripto no han tenido rrazón; escribir mas de aquello que es por que cierto los naturales desta isla de Luzón, que comúnmente llamamos los españoles moros, ellos no lo son, porque en verdad es que ellos no saben la ley de Mahoma, ni la entienden; solamente en algunos pueblos orilla de la mar no comen puerco, y esto es por aver tratado ellos con los moros de Burney, que les han predicado alguna parte de la secta de Mahoma; é porque adelante trataré más largo en lo que toca á los rritos é çirimonias destos naturales, diré lo primero las guerras que con ellos an tenido los españoles, sin quitar ni poner cosa ninguna demasiado, porque ansí me lo a encargado una cierta persona que me lo mandó scrivir, y desta manera se entenderá sin sospecha ninguna la defensa que de estos naturales ay, por que el que esto leyere sepa la verdad de lo que acá pasa, Manila, 1572, p. 29. La relación completa la editó W.E. RETANA, Archivo del Bibliófilo Filipino. Recopilación de documentos históricos, científicos, literarios y políticos y Estudios Bibliográficos, Madrid, 1898, vol. 4, pp. 1-37. 
quista no atendería tanto a pactos y respeto de propiedades, sino que como enfrentamiento con el islam, la guerra y el botín estarían justificados. Ésta es la línea ideológica y argumental que sostiene Melchor de Ávalos y otros que defienden los mismos intereses evangelizadores.

Como se desprende del texto, a través del comercio con Brunei cierta población de las costas del sur de Luzón y de la bahía de Manila empezaría a seguir prácticas semejantes. Las familias aristocráticas de Manila y Brunei estarían emparentadas -como durante la expedición de Magallanes se pone de relieve-, lo que igualmente supondría que los vasallos empezarán a seguir las prácticas de los amos. Así, sin duda una incipiente islamización estaría teniendo lugar en Manila. Identificar este preliminar proceso con la tradición secular del islam occidental será la estrategia empleada por los sectores más reaccionarios del establecimiento español con el fin de tomar vidas y propiedades. Dado que Felipe II permite la esclavización de población musulmana que haga proselitismo, afianzar la islamicidad del archipiélago suponía mayores prerrogativas en el abuso que se pudiera hacer de la población local.

Así, del mismo modo que a finales del siglo XVI un debate estaba germinando en la Península sobre el "problema morisco" ${ }^{26}$, en el archipiélago se producirá otro sobre "el problema moro". En 1585 las Alegaciones de derecho del licenciado Melchor de Ávalos, oidor de la real audiencia de Manila, para la S.C.M.R. acerca de los mahometanos de las Philipinas y contra ellos responderán y seguirán insistiendo sobre la islamicidad de los moros filipinos, a través de un centón jurídicamente argumentado con autoridades latinas y fuentes portuguesas, rogando a Felipe II una nueva y más enérgica respuesta.

Consecuentemente, las dos cartas apologéticas redactadas por el oidor de la Audiencia de la recién fundada ciudad de Manila, Melchor de Ávalos, dirigidas al rey en 1585 son el primer documento histórico centrado exclusivamente en la presencia islámica en el archipiélago filipino. Su principal propósito será vincular a los musulmanes filipinos con una red islámica desde occidente a oriente y, en tal sentido, bajo las mismas directrices ideológicas que se entendía el islam occidental. La conexión con el islam ibérico de origen andalusí será definitivamente subrayada, poniendo por primera vez en relación la expansión islámica en Asia oriental como consecuencia de los hechos acaecidos al islam en occidente. Si para los portugueses el encuentro con el personaje de Monçaide era una anécdota diplomática ${ }^{27}$, para los españoles la pre-

26. Cfr. M.Á. de BunEs, Los moriscos en el pensamiento histórico, historiografía de un grupo marginado, Madrid, 1986.

27. "Just arrived to Calicut [...], they [los portugueses] meet Monçaide (El-Mas'ud), a Muslim from Tunis, who welcomes them in a mixture of Spanish and Portuguese, Eveio con ele un daqueles mouros, o qual, tanto que foi em os navios, começou de dizer estas palavras, -Buena ventura! Buena ventura! Muitos rubis, muitas esmeraldas! Muitas graças debéis de dar a Deus por vos trazer a terra onde há tanta riqueza! Era para nós isto de tanto espanto, que o ouviamos falar e não o críamos-que home 
sencia del islam en el archipiélago filipino, y en la propia ciudad de Manila, no podía sino remitir a la conquista territorial de al-Andalus (articulada ideológica, territorial y económicamente bajo el proyecto nacional de la reconquista).

Para Melchor de Ávalos la respuesta estaba clara: el islam era una red internacional, y los propios musulmanes que habían luchado en Lepanto se encontraban en el sudeste asiático. Bajo esta concepción ideológica, los musulmanes filipinos debían correr la misma suerte que los musulmanes ibéricos dentro de un imperio teocrático legitimado por el catolicismo:

"Assí que como de todos los otros sus Reynos, puede y deve V. M. echar y expeller a los moros de todas las Yslas Philipinas del archipiélago y a lo menos subjetarlos y hazerlos tributarios, debellando los de las Javas y Samatra, Achen, Borney, Mindanao, Xoloc, Malucos, Malaca y de Siam y Patán, Pegu, y otros Reynos en que se adora Mahoma, cuya veneraçión y mala secta traxeron por acá persas, y arabios, y egipcios, y turcos, y aun vinieron moros de Túnez y de Granada, algunas vezes en armadas del Campsón, Soldán que fue del Cayro y Rey de Egipto, como en muchas partes se collige de las historias de Portugal y espeçialmente de la que escrivió en buen latín el obispo de Algarve don Iherónimo Ossorio por mandado de la magestad del señor Rey don Enrique, siendo cardenal, lib. 4, fol. mihi 342, adonde dize que vinieron a la Yndia contra Alonso de Albuquerque, capitán general del glorioso señor Rey don Manuel, abuelo de V. M., emviados del dicho Soldán en una armada veynte y siete navios y galeras, seteçientos mahometanos mamelucos, y trezientos turcos y mill moros de Túnez y de Granada, cuyo general se dezía Solimán, turco de naçión [...] Assí que me pareçe que entran en la cuenta estos moros de las Yslas Philipinas, mayormente que, como está dicho, vienen de Egipto y de Arabia y de Meca, y son parientes, disçípulos y miembros suyos, y cada año dizen que vienen a la Samatra y a Bomei turcos, y a Ternate, adonde están abra algunos de los vençidos en la famosa batalla naval que dio el señor don Jhoan de Austria. Y a otras islas del Maluco tanbién vienen y suelen venir a predicar la secta, y dar avisos para guerra contra christianos" 28 .

Como se desprende del texto, el propósito de Melchor de Ávalos era legitimar la conquista territorial de las regiones islámicas no sólo del archipiélago filipino, sino incluso del sudeste asiático. Del mismo modo que la

houvesse tão longe de Portugal que nos entendesse nossa fala! What Monçaide spoke was not Portuguese, but a corrupt form of Spanish. Despite this, finding the familiar in the unknown had a very strong effect on the seamen", en E. LOSADA SOLER, «The Encounter of Languages, Reflections on the Language of the Other in Roteiro da Primeira Viagen de Vasco da Gama», en A. DISNEY y E. Воотн, Vasco da Gama and the Linking of Europe and Asia, Oxford, 2000, pp. 207-208. El encuentro con Monçaide aparece inmortalizado en Os Lusíadas, "Entre a gente que a vê-lo concorria, / Se chega un Maometa, que nacido/ Fora na região da Berberia/ [...] Em vendo o mensageiro, com jucundo/ Rosto, como quem sabe a língua Hispana, / Lhe disse, Quem te trouxe a estoutro mundo, / Tão longe da tua pátria Lusitana?/ Abrindo, lhe responde, o mar produndo/ Pon onde nunca veio gente humana; / Vimos buscar do Indo a gras corrente, / Por onde a Lei Divina se acrecenté", Luís de Camões, Os Lusíadas, Mem Martins, 1997, VII, pp. 24-25.

28. Primera carta-tratado, $\S 6$ y 8 . 
monarquía hispánica había bloqueado la expansión del islam en occidente, el oidor de Manila recomienda encarecidamente al rey español que pase a ser el freno del islam en el extremo oriente. Más que una relación histórica basada en datos reales, Melchor de Ávalos crea un texto propagandístico en base a la información que dice poseer, argumentando incluso que granadinos y moriscos tunecinos participaban en la islamización del sudeste asiático, especialmente tras la conquista portuguesa de Malaca en 1511 como una contraofensiva islámica.

Melchor de Ávalos cita fuentes portuguesas sobre la presencia islámica en el océano Índico, incluso el dato sorprendente de que los mismos soldados que habían luchado en la batalla de Lepanto contra los españoles se encontraban ahora en el sudeste asiático. La veracidad de este hecho parece ciertamente cuestionable. Sin embargo, y a pesar del propósito propagandístico de Melchor de Ávalos, tras la conquista del Egipto mameluco en 1517 y la ruina del Mediterráneo tras Lepanto en 1571 el imperio otomano centró su atención en frenar a los portugueses en el Índico. Dentro de este contexto tiene lugar una campaña de ayuda militar al sultanato de Aceh en Sumatra dirigida por los otomanos en 1568, presencia militar otomana en el sudeste asiático que aún no ha sido completamente estudiada ${ }^{29}$.

Así pues, a pesar de las exageraciones apologéticas de las cartas de Melchor de Âvalos, se puede colegir que ciertos visos de veracidad existirían en sus aseveraciones, en cuanto que población islámica se dirigía al sudeste asiático como nuevo escenario de confrontación islamo-cristiana: los portugueses habían usurpado el imperio talasocrático islámico, el Mediterráneo se había convertido en un mar de piratas y los españoles empezaban una conquista territorial del continente asiático. El siglo XVI será testigo del nacimiento del mundo moderno, nacimiento que será consecuencia de la desintegración de las limitaciones geográficas de la antigua ecúmene y, a la par, del mundo islámico.

Los españoles no tardaron en darse cuenta de que los musulmanes controlaban el comercio del archipiélago al revender los productos chinos. No era tanto el antagonismo ideológico ${ }^{30}$, sino la rivalidad comercial y, a fin de cuen-

29. Sobre la presencia otomana en el océano Índico en el siglo XVI véanse P. JOHNSON BRUMMETT, Ottoman Seapower and Levantine Diplomacy in the Age of Discovery, Albany, 1994; Salih ÖzBARAN, The Ottoman Response to European Expansion, Studies on Ottoman-Portuguese Relations in the Indian Ocean and Ottoman administration in the Arab lands during the sixteenth century, Estambul, 1994; Id., Ottoman Expansion Toward the Indian Ocean in the 16th century, Estambul, 2009; y Giancarlo CASALE, The Ottoman Age of Exploration, Oxford, 2010.

30. " "[...] y que si por caso topasen juncos chinos o de Borney y de otras partes, sin les hacer mal ni daño alguno, procurasen hacer paz con ellos, porque esto es lo que acá principalmente se pretende", en Relación de los acontecimientos del viaje y jornada que hizo la armada de S.M. al mando del general Miguel López de Legazpi, en P. Hidalgo NuCHERA (ed.), Los primeros de Filipinas. Crónicas de la Conquista del Archipiélago de San Lázaro, Madrid, 1995, p. 170. 
tas política, la que haría pronto surgir el enfrentamiento ${ }^{31}$. No obstante, no quedaba otra opción a los pocos españoles que acometían la conquista de un archipiélago de centenares de islas que asumir en un primer momento el orden de la talasocracia local ${ }^{32}$. A diferencia de los portugueses que controlaron puertos estratégicos de fama mundial, los españoles se enfrentaban a un escenario desconocido disperso y con la intención no de controlar la red marítima, sino el espacio terrestre.

Los españoles lograrán controlar las áreas en las que el islam no estaba implantado con la suficiente institucionalización política como para oponer resistencia. No obstante, no sucederá lo mismo con los sultanatos de Sulú y Mindanao en donde, tras la aparición de los españoles y el colapso del comercio regional que estaba en manos de los musulmanes, se darán las condiciones idóneas para la perpetuación de las estructuras basadas en el tráfico de esclavos. Así, dada la fugacidad de la frontera, las agresiones y ataques para obtener cautivos se convertirán en el modo de legitimación de la numerosa aristocracia musulmana, y también servirán para calibrar su riqueza y poder (en razón del número de esclavos y partidarios).

Por su parte, la política española será diferente, basándose en la primera acción histórica que de forma explícita propugna la conquista territorial del otro hemisferio. Si Portugal pretendía usurpar y reemplazar el imperio talasocrático islámico, España pretende una conquista efectiva de extensiones territoriales asiáticas. Para Portugal el encuentro con el andalusí exiliado en Asia no será más que un elemento anecdótico, embajadores con los cuales negociar ventajosamente en lengua castellana. Para España el encuentro, no sólo con el andalusí, sino con el propio islam en el hemisferio oriental, supondrá un verdadero interrogante histórico. Los reinos cristianos ibéricos habían frenado e incluso acabado con el occidente islámico, y ahora se veían en la situación de confrontar y dirigir los destinos del extremo oriental islámico.

31. “El Capitán y oficiales de su Majestad dijeron que habían hallado en el puerto de Butuán dos juncos de la isla de Luzón, en que venían ciertos moros mercaderes que estaban contratando con los naturales de la tierra [...] Los naturales de Butuán venían al patache a contratar con los españoles, pero los moros se lo procuraban estorbar; y si los indios vendían a los del patache algunas cosas a trueque de tafetanes y lienzos, les hacían los moros deshacer el concierto diciéndoles que les engañaban los españoles en darles aquellos géneros; y que si les vendiesen alguna cosa fuera a trueque de plata, lo cual hacían los moros con el deseo de quedarse con todo el dinero que el patache traía", en G. de SAN Agustín, Conquista de las Islas Filipinas, Madrid, 1974, p. 172.

32. “Todo esto disimulaba el Gobernador conociendo la necesidad que tenían del contrato con los moros [de Luzón] los cuales les sirvieron, especialmente el principal de ellos, Mahomar, porque siempre fue muy amigo de los cristianos y persuadió con su industria a muchos naturales de otras islas para que los fuesen", en ibídem, p. 235. 


\section{LA SIGNIFICACIÓN DE LOS ARGUMENTOS DE ÁvALOS RESPECTO A LOS MUSULMANES PENINSULARES}

Miguel López de Legazpi (c. 1503-1572) ${ }^{33}$ se dará rápida cuenta de la multiplicidad antropológica del archipiélago, escribiendo que si los moros controlan el comercio, no eran numerosos más que en Brunei y Manila, siendo el resto de población gentil. De tal manera explica en la relación que remite al rey la situación y la facilidad con que puede hacerse la expansión de la fe cristiana y, en consecuencia, la conquista territorial:

“En esta ysla [de Luzón] ay muchas provincias y en cada una de ellas hay diferente lengua y costumbres -la mayor parte es de moros mahometanos y otros indios que se pintan, que adoran a sus pasados, invocan el demonio-, no tienen Rey natural -señorean la tierra señores particulares- los mas ricos de ellas, tienen guerras unos con otros y se captivan y se hazen esclavos y venden de unas provincias á otras [...] Estos naturales seran faciles de convertir a nuestra santa fee catolica porque casi todos son gentiles sacando los de borney y luçon que son moros por la mayor parte y algunos principales que an convertido en estas islas y aun estos tienen poca noticia de la ley que tomaron mas de circuncidarse y no comer puerco -pero los gentiles estan sin ley y no tienen templos ni ydolos ni sacrificios y fácilmente admiten lo que se les dize y persuade- tienen algunas supersticiones y de no hazer cossa ninguna sin que primero echen suertes y otras miserias que todo sera facil de quitarles aviendo rreligiosos que sepan la lengua y les prediquen" ${ }^{\prime 34}$.

Legazpi llegará a solicitar al rey la posibilidad de esclavizar a los moros que entorpezcan la expansión española o propaguen el islam. Dada la existencia de este espíritu en España, la respuesta e instrucción de Felipe II a Legazpi da muestras de una actitud tan benévola, como pragmática, pues ordenaba que: “bajo ninguna consideración deberéis hacer esclavos a aquellos indios que hayan adoptado el culto de Mahoma; pero trataréis de convertirlos y de persuadirlos a aceptar nuestra santa fe católica por medios buenos y legítimos".

No obstante la respuesta del rey, Melchor de Ávalos seguirá insistiendo en el argumento y solicitará que sea reconsiderada la posibilidad de esclavizar a los musulmanes del archipiélago ${ }^{35}$. Es curioso cuál es su recorrido argumental para

33. Felipe II encomendó a Andrés de Urdaneta (c. 1508-1568) y Miguel López de Legazpi (c. 15031572) la organización de una misión de conquista y poblamiento de las Islas del Poniente. Cfr. P. Hidalgo Nuchera (ed.), Los primeros de Filipinas y Colección de documentos inéditos relativos al descubrimiento, conquista y organización de las antiguas posesiones españolas de ultramar, Madrid, 1887, tomo 3.

34. Legazpi. Relación de las Islas Filipinas, 1570, Archivo General de Indias, Filipinas, L1-1-2/24. Edición en W.E. RETANA, op. cit., vol. 5, pp. 39 y 24.

35. "He [Ávalos] petitioned for a suspension of the law forbidding slavery in order that Spaniards might avail themselves of captive Moros as slaves", Ch.H. CunningHam, The Audiencia in the Spanish Colonies, as Illustrated by the Audiencia of Manila, 1583-1800, Berkeley, 1919, p. 57. Sobre la cuestión de la esclavitud en Filipinas véase W.H. ScotT, Slavery in the Spanish Philippines, Manila, 1997. 
llegar a este punto final: su rigorismo jurídico así como dogmatismo católico le llevarán a analizar la situación de derecho del estatus en que se encontraban los musulmanes dentro del nuevo estado filipino establecido por los españoles. Aduce que musulmanes expulsados de España, egipcios controlando el océano Índico, árabes predicando en las regiones orientales y turcos vencidos en la batalla de Lepanto, todos juntos fueron islamizando paulatinamente el archipiélago malayo hasta llegar al filipino. En consecuencia, dado que existía una vinculación internacional entre musulmanes desde España hasta Filipinas, el rey católico de España estaba en la obligación de combatir a los musulmanes del archipiélago. Aunque reconoce que la población indígena era musulmana sólo de nombre y poco conocimiento tenían del islam, afirma sin vacilación que la lucha debe ser llevada a cabo, una lucha militar, económica y religiosa de evangelización.

Melchor de Ávalos representará la posición más radical en contra de las ideas pacíficas en la colonización de Filipinas, comparando el modelo asiático con el español, cuando las controversias sobre los moriscos estaban más candentes. Así pues, ningún diálogo podía ser posible con musulmanes, y el único remedio posible era el exilio o la guerra abierta.

De este modo se irá formando un partido político entre los primeros pobladores españoles del archipiélago, quienes harán apología de la enorme expansión que según ellos el islam poseía en las islas, y la necesidad de una respuesta enérgica por parte de la administración española. Se emplearán argumentos propios de la realidad occidental, argumentándose que gacices y morabitos estaban llevando a cabo una conversión acelerada de la población del archipiélago:

"Hay en esta isla [Manila] y en la de Tondo muchos mahometanos, a quienes se les había pegado la secta por la contratación que tenían en Borneo. Los cuales habiéndose casado en las islas, y avecindándose en ellas, se la habían pegado, y enseñado, dándoles cartillas, ceremonias y forma de guardarlas. Y así muchos de la isla [de Luzón] comenzaban a ser moros retajándose y poniéndose nombres de moros; y cundía el cáncer tan de prisa que a tardarse más la llegada de los españoles todos fueran hoy moros, como lo son ya todos los isleños que no están en el gobierno de Filipinas, a los cuales tienen muy industriados gacizes y otros moravitos que les vienen a predicar por el estrecho de Meca y Mar Rojo"36.

Ciertamente el dato es de gran importancia, pues parece definitivamente que con el colapso del Mediterráneo, el exilio de miles de moriscos, el auge internacional de los turcos otomanos y la ruina económica de miles de familias musulmanas por la usurpación marítima portuguesa, el océano Índico en el siglo XVI pasó de representar el gran comercio del mundo para el islam a ser el escenario de los grandes exilios. Como una batalla de guerrillas, musulmanes de todos los puntos del mundo islámico se dirigirán al sudeste asiático, escenario en el cual se debatirá la hegemonía económica, política y religiosa de

36. J. de GRIJALVA, Crónica de la orden de nuestro padre san Agustín en las provincias de Nueva España, México, 1985, p. 492. 
un orden internacional que veía nacer el mundo moderno, un orden en el que Europa es cada vez más poderosa, mientras que el islam ve reducirse sensiblemente su influencia:

“[...] se han enseñoreado [los musulmanes] de la parte septentrional de la Somatra de dozientos, o poco más años á esta parte, valiendose primeramente del comercio, luego de los casamientos, y ultimamente de las armas. Passando adelante han ocupado la mayor parte de los puertos de aquel inmenso Archipielago, señores de la ciudad de Sunda en la Iava en Borneo y en Gilolo, y avian entrado hasta Luzon isla nobilissima entre las Filipinas, y edificado ya en ella tres poblaciones [...] Y si no se les opusieran los Portugueses en la India y en el Maluco, y despues los Castellanos en las Filipinas; y no hubieran con las armas y con el Evangelio atajadoles el passo, y cortado el hilo a su corriente, sin duda poseyeran el dia de oy infinitos Reynos de aquel Levante" ${ }^{137}$.

Con los moriscos de España se mostraba muy escasa piedad. Es más, presionando continuamente a la monarquía española existió una línea de intereses económicos, entretejida con una postura doctrinal intransigente contra este colectivo. Según Martín Hume: "Se había decidido prácticamente en cierto momento (1581) por Felipe II embarcar a toda la población morisca y hundir los barcos que la transportaban. Gómez Dávila de Toledo apremió a Felipe III en 1598 para que los matara a todos, mientras otros más humanos abogaban por que les fueran quitados por la fuerza todos los niños, la esterilización de los varones y otras medidas heroicas. Durante algún tiempo también los espíritus más suaves rogaron que se ensayaran métodos más benignos, pero la actitud de los moriscos mismos y el fanatismo de los eclesiásticos pronta silenciaron la voz de la piedad"38. A la postre, no fue Felipe II el Prudente (1527-1598), sino su hijo y sucesor Felipe III (1578-1621) quien consumara este tercer genocidio habido en tierras peninsulares.

Los moriscos no encontraron una vigorosa protección eclesiástica, como ocurrió con los naturales en las Filipinas ${ }^{39}$. Al contrario, fray Jaime Bleda llegó tan lejos como para pedir la matanza de los moriscos en España como un "piadoso deber cristiano" ${ }^{40}$. Incluso Vitoria y Guerrero habían creído que debía hacerse

37. J. Rebullosa, Historia eclesiástica y estado presente de la Religión en todos los reynos de Europa, Asia, y Africa, sacada de las Relaciones Toscanas de Iuan Botero Benes, Barcelona, 1610, folio 132.

38. M. Hume, The Court of Philip IV, Londres, 1907, pp. 23-24 (trad. esp., La corte de Felipe IV. La decadencia de España, Sevilla, 2009, 421 pp.). Vid. también H.C. LEA, The Moriscos of Spain, Filadelfia, 1901, capág. X (trad. esp. Los moriscos españoles. Su conversión y expulsión. Estudio preliminar y notas R. Benítez Sanchez-Blanco, Alicante, 1990, reimpr. 2001).

39. Ya en 1570 Fray Diego de Herrera protestaba al rey, "No creo que pueda darse ninguna otra razón como autoridad para robarlos, salvo el que son moros; y ésa no es razón legítima", Carta del agustino Diego de Herrera sobre el mal estado de las Filipinas, Archivo General de Indias, Sevilla, Filipinas, 84, N.1. La carta está fechada el 25 de julio de 1570.

40. Defensio fidei in causa neophytorum, sive morischorum Regni Valentiae, totiusq. Hispanice ... et Tractatus de insta morischorum ab Hispania expulsione, Valencia, 1610, cfr. la edición y estudio de 
guerra perpetua contra los sarracenos. Cuando vemos cuán interiorizadas estaban estas doctrinas por ciertos estamentos formados en el derecho canónico tradicional que se enseñaba en las universidades españolas, más nos damos cuenta de las limitaciones y dificultades que debía suponer el desarrollo de un estado moderno asentado sobre estas bases doctrinales fundadas en la religión cristiana. Éstas constreñían el ámbito de actuación del gobernante de modo estricto y negaban cualquier heterogeneidad, y mucho menos dentro de lo religioso.

Comprendiendo cuál fue la postura de determinados grupos de la élite administrativa española en Filipinas acerca de los musulmanes que allí se encontraron, hemos buscado iluminar y entender cuáles eran los condicionantes de los gobernantes a la hora del gobierno y del trato de poblaciones musulmanas.

En este caso concreto, Felipe II, frente a los memoriales de Melchor de Ávalos y de otras noticias que le llegaron de Filipinas, adoptó una política de gobierno realista y no sólo alejada de las peticiones de represión, esclavización y guerra que le llegaban, sino incluso puede pensarse que conciliadora y frenadora de estos espíritus exaltados. No obstante, si bien desde la Península se alentaba una política de atracción, la imprudencia de los agentes gubernamentales en el terreno filipino, los intereses estratégicos y económicos en la región, y la fragilidad de las fronteras en un mundo insular, encendieron un conflicto entre comunidades religiosas que aún pervive en el archipiélago filipino, conociéndose históricamente como el "problema moro".

este memorial por Josep Puig MonTADA, en los Mélanges en l'honneur de Dominique Urvoy, editados por Nicole Koulayan et Mansour Sayah, Estrasburgo (en prensa). Según H.C. Lea, "Fray Bleda demostró con autoridades irrefragables que todos los moriscos podían ser asesinados en un solo día, o que el rey podía condenar a todos los adultos a muerte y al resto a esclavitud perpetua, o venderlos a todos como esclavos a Italia o las Indias, o llenar con ellos sus galeras ... Urgía la matanza de preferencia a la expulsión, arguyendo que sería una obra de gran piedad y edificación para los fieles y una saludable advertencia para los herejes ... y si se les amontonaba en la costa africana, agravarían, al morir, la peste, que el año antes se había llevado a cien mil sarracenos. La obra de Bleda no sólo fue aprobada por todas las autoridades en España, y los gastos, de su impresión sufragados por Felipe, sino que cuando su rival Fonseca trató de impedir su introducción en Roma, fue examinada autorizadamente y declarada libre de error, y Clemente VIII la leyó con agrado por indicación de su confesor, el cardenal Baronio", en op. cit., pp. 298-299. La opinión de Bleda es coherente con una línea de polémica antiislámica muy intensa en la Península Ibérica, con escritos desde los propios de los mozárabes del s. IX (Francisco FRANCO-SÁNCHEZ, «La conquista musulmana del Magreb y al-Andalus según las crónicas mozárabes», Dirāsāt fì l-ațār wa-l-naqā'iš wa-l-tārīj, takrīman li-Sulaymān Muștafá Zbīs. Mélanges d'archéologie, d'épigraphie et d'histoire offers à Slimane Mustapha Zbiss, Túnez, 2001, pp. 285-307), pasando por los escritos de Pedro el Venerable (Cluny, ca. 1092-1156; J. TOLAN, «Peter the Venerable on the «diabolical heresy of the saracens»», The Devil, Heresy and Witchcraft in the Middle Ages. Essays in Honor of Jeffrey B. Russell, ed. A. Ferreiro, Leiden, 1998) y otros posteriores y conocidos, como el tratado Sobre la seta mahometana del obispo de Jaén Pedro Pascual (Valencia, ca. 1227 - Granada, 1300; ver John TolAN, «Barrières de haine et de mépris. La polémique antiislamique de Pedro Pascual», Identidad y representación de la frontera en la España medieval (siglos XI-XIV). Seminario celebrado en la Casa de Velázquez y la Universidad Autónoma de Madrid, 14-15 de diciembre de 1998, Madrid, 2001, pp. 253-266). 


\title{
APÉNDICE DOCUMENTAL
}

Manuscrito original, firmado, en el Archivo General de Indias de Sevilla: [Filipinas, leg. 18A, R.3, N.19]. El expediente se compone de dos cartastratados con otra introductoria. Las dos cartas fueron editadas bajo el título de «Dos cartas al Rey contra los moros de las Filipinas »por L. HANKE: Cuerpo de documentos del siglo XVI. Sobre los derechos de España en las Indias y las Filipinas. Descubiertos y anotados por Lewis Hanke. Compilador Agustín Millares Carlo, México, ed. Fondo de Cultura Económica, 1943, pp. 65-115. Realizamos una nueva edición de las dos cartas consultando directamente el manuscrito original, teniendo en cuenta los siguientes criterios: se mantiene la ortografía del texto pero se actualizan los acentos a la norma actual; se añaden los signos de puntuación mínimos para una mejor lectura; se escriben en mayúsculas los nombres propios; se redactan en cursiva los textos y citas latinas; no se expanden las palabras abreviadas y se mantiene la división en epígrafes del original. En cuanto a las notas explicativas, incluimos algunas procedentes de la edición de Hanke, y añadimos otras en torno a las fuentes del derecho canónico y el contexto en el que se gesta el documento.

Por motivos de extensión del artículo, hemos debido dividirlo en dos partes. En esta primera parte publicamos junto al estudio inicial, la Segunda carta de Melchor de Ávalos, más breve que la precedente La primera carta será publicada en un próximo número de esta misma revista.

\section{Segunda carta y alegaciones de derecho de lic. ${ }^{\text {do }}$ M. ${ }^{\text {or }}$ de Ávalos oidor de la real audiencia de Manila para la S.C.M.R. acerca de los mahometanos de las Philipinas y contra ellos [Manila, 1585]}

\author{
$\dagger$ \\ Sacra Cesarea Magestad Real
}

1. Después de aver escrito la primera que va con ésta y mi pareçer sobre las conquistas que se podrán hazer a los mahometanos de estas Yslas Philipinas, se ofreçieron otras algunas dudas de los religiosos y del obispo que son de mucha importancia y conviene advertir a V. M. y a los de su muy alto consejo de las Yndias, y dezir en ellas mi pareçer.

2. La primera duda es si tienen jurisdiçión esta Real audiençia en la temporal y el obispo y religiosos en lo eclesiástico para proçeder y juzgar contra los gentiles infieles por ser ydólatras y no reconoçer un solo dios criador de todas las cosas, y pecar contra la ley de naturaleza.

3. Aviendo tratado con los dichos religiosos se resolvieron y fundaron en dezir que V. M. no tiene ni sus audiençias poder ni jurisdiçión ni averla tenido el pontífiçe Alexandro sexto in actu para poderla dar contra los ydólatras, antes de averse baptizado, y traen la authoridad de 
Sant Pablo, $1^{\circ}$ ad Romanos 5 cap. ${ }^{41}$, adonde dice, quid enim mihi de iis, qui joris sunt, indicare? Diéronme esta opinión por escrito los de Sant Francisco y de Sant Agustín, y de palabra el obispo.

4. En esto llevan un presupuesto y fundamento condenado que es contradezir la potestad del pontífiçe, y se van por la opinión de algunos theólogos y canonistas, y contra la opinión de Hostiense que es la más común y faboreçedora de la fee, según yo la tengo bien fundada en la dicha carta, y basta que el papa Alexandro sexto siendo tan santo y sapientíssimo con acuerdo de sus cardenales siguió y abraçó la dicha opinión de Hostiense quando hizo la Bula de la graçia y conçedió a las casas de Castilla y Portugal el resto que avía del mundo y dio las jurisdiçiones y dominios a los señores Reyes Cathólicos y suçessores. La qual conçessión an revalidado y confirmado con otros muchos indultos y bulas las papas que a havido en la yglesia de Dios, desde Alexandro a esta parte, y sacrílego y herético es dudar y contradezir açerca de la potençia de la yglesia, según más largamente dixe y se persuade por el cap. Si quis suadente, § Committitur, et seq., $q .{ }^{e} 4 .{ }^{42}$ Cum enim Papa sit supra omnia iura mundi, haereticus erit oppugnare privilegia Ecclesiae, in cap. Nulli fas est, distinct. $19^{43}$; y dize el maestro Victoria in Repetitione De potestate Papae et Concilii, nu. 17, estas palabras, quia profecto hoc esset in turbationem et dissolutionem ecclesiasticae hierarchiae et auctoritatis, si quilibet posset dicere, Papa non potest; de quo pullularunt haereses. Remítome a lo que en la dicha carta dixe, por no repetir muchas vezes una misma cosa, y assí, siendo la conçesión validíssima y tan cathólica, queda el fundamento contrario confundido y deshecho y no se puede dudar so la dicha pena.

5. Conforme a lo qual, teniendo V. M. in actu et in habitu las jurisdiçiones y dominios contra infieles super gentes et regna mundi, nadie puede negar el supremo, y universal poder que indubitablemente tiene en estas yslas contra todos los infieles, ydólatras y pecadores in legem naturae, no solamente en las partes adonde los dichos gentiles biven entre christianos, sino también adonde biven aparte, porque quando biven entre christianos, no dudan los dichos religiosos de que tenga V. M. en lo secular jurisdiçión, y ellos en lo spiritual, por razón de evitar el escándalo que resultaría a los que son fieles de ver ydolatrar a los ynfieles. Assí que también en las yslas y partes adonde no ay baptizados gentiles, me pareçe que podemos los ministros de V. M. castigar los pecados de ydolatría y abominaçiones y delitos que se cometen contra la ley de naturaleza, y basta que con estos pecados se ofende Dios y se escandalizan los christianos castellanos; y quántos y quáles sean los pecados contra legem naturae, sería muy largo referirlos, según el maestro Victoria in Relectione De Indis, pag. mihi 345, ibi, item nec omnia peccata contra legem naturae possunt evidenter ostendi. Bien hace Sant Pablo la difiniçión de la ley natural, ad Romanos, cap. $2^{44}$, ibi, sibi ipsi sunt lex, qui ostendunt opus legis scriptum in cordibus suis, testimonium reddente illis conscientia ipsorum, tx. in cap. Ius naturale, $1^{a}$ distinct. ${ }^{45}$, in lege 2 , tt. 1 , pda. 1. Et lex naturae per Cicerón em ita diffinitur, est ratio summa insita in natura, quae iubet ea quae facienda sunt, prohibet contraria. Et, ut inquit Oldendorpius in tractatu De Iure naturali, vol. 7 Tractatuum, nu. 6 et 12, lex ista naturae praecepta decalogi continet, et ante nata est, quam lex ulla scripta, et ante quam civitas aliqua constituta. Bien declara el prinçipio y virtudes y obligaçiones de la ley natural el padre fray Thomás de Mercado desde la primera hoja de su libro de la Suma de

41. El original trae " 1 ad Romanos 5", pero la cita corresponde a la Epístola 1 ad Cor., c. 5, vers. 12.

42. Decreto de Graciano, segunda parte, causa 17, q. 4, c. 29.

43. Ibid., primera parte, dist. 19, c. 5 .

44. Vers. 14-15.

45. Decreto de Graciano, primera parte, dist. 1, c. 7 . 
contratos y cuenta algunos capítulos della que tenían los Romanos, fol. 6, col. 2: "Llegaréis os a Dios con ánimo y cuerpo casto, honraréis a los padres y mayores, no adoraréis dioses agenos; quien jurare falso sea castigado con pena divina y humana y sea infame; quien conoçiere parienta suya muera por ello; guardaréis fielmente las treguas y pazes que hizierdes con vuestros enemigos; seréis prestos en cumplir los votos que prometierdes a dios, etc".

6. Ésta fue opinión del papa Inoçentio y de Abbad, nu. 12, y de Felino, nu. 1 in cap, Quod super his, De voto, y de Ancharrano y Hostiense y Jhoan Andrés. Lo mismo dice Abbad in cap. Novit, De iudiciis, nu. 2, quod etiam infideles denuntiari possunt, si peccant contra legem naturae vel idola colunt, quia proximi sunt omnes infideles quos debemus diligere, et lucrifacere quantum possumus, secundum humanitatem et nostrae naturae participes. Lo mismo dice Felino allí, nu. 1, in cap. Novit; Albertinus in rubrica De haereticis, lib. VI, q. ${ }^{e}$, vers. Quaero an si quis crederet plures déos, fol. mihi 13, col. 1, nu. 51; Marquardus in parte 2 libri Contra inimicos Crucis Christi, cap. 9, in principio, fol. 99 et fol. 57, col. 1. Collígese de el doctor Navarro in Repetitione cap. Ita quorundam, De ludaeis et Sarracenis, pag. mihi 160; Felinus in cap. I De constitutionum limitatione 5; y aunque el maestro frai Domingo de Soto, lib. 5, De lustitia et iure, q. ${ }^{e}$, art. 5, in fine, pag. mihi 420, diga se nolle discutere nec docere quis sit iudex contra idolatras y lo dexa como indeçiso y reservado para determinarse in libro De ratione promulgandi Evangelium, el qual no a salido a luz impresso, que yo aya visto ni sabido, pero él mismo en la plana antes que es 419, hablando de infidelibus tertii ordinis que son los ydólatras dize estas palabras refiriendo a Sancto Thomás, $2^{a} 2^{a}, q^{e}{ }^{e} 10$, art. 10, in primis enim non negat licitum eis fuisse infideles propter idolatriam iussu Dei debellare, sed tantum negat eo solum quod infideles essent secus ob idolatriam. Y assí yo siempre e presupuesto lo mismo que a los simplemente infieles no se podrá hazer guerra ni daño sin las premisas que en el predicarles an de hazerse para que bivan bien, pero los que demás de ser infieles son ydólatras et agunt contra legem naturae (que es esto de que voy hablando) tengo por muy llana esta opinión y la comprueva sapientíssimamente Gregorio López in Repetitione De bello, posita supra l. 2, tt. 23, pda. 2, fol. 81, in tt. 5 contra idolatras et cultores contra legem naturae, et fol. 82, col. 4, et seq. Collígese lo mismo del obispo Simancas, tt. 31, De haereticis, nu. 4, fol. 140 ibi, nam si baptizatus non esset. Idem Simancas in tt. 32, num. penul., alegando a Albertino ubi supra pareçe que passa con esto, y que aunque los ynquisidores no conozcan contra moros no baptizados ni ydólatras, pero podrán los ecclesiásticos y seglares. Silvestro in Summa, in verbo Infidelitas, nu. 4 et nu. 8; Castro, De iusta haereticorum punitione, lib. $1^{\circ}$, cap. 7 et cap. 23, col. 2. Esto mismo entendió Sancto Thomás ubi supra q. ${ }^{e} 10$, art. 8, fol. mihi 29 , col. $l^{46}$, ibi, sunt tamen compellendi a fidelibus si adsit facultas. Y es muy de notar la doctrina del mismo sancto doctor en la misma $q .{ }^{e} 10$, art. 2 , in fine, cuyas palabras son, propter hoc etiam haereticorum et paganorum ritus aliquando Ecclesia toleravit, quando erat magna infidelium multitudo, de manera quod secus erit si facultas adest et potentia contra infideles idolatras vel offendentes legem naturae. Esta palabra dize Albertino ubi supra, ibi, non video quare Papa, qui est vicarius Iesu Christi, non possit et etiam debeat, dummodo facultas adsit; idem docet Marquardus, ubi supra, fol. 99, nu. 1 et fol. 100, nu. 5, alegando muchas doctrinas, y que quando se dio el poder a Sant Pedro por el Redemptor, Pasce oves meas, se entiende y entendió tam de fidelibus quam de infidelibus, cum etiam infideles per creationem sunt oves, licet non de ovili sacro, et infideles, velint nolint, de ovili sunt, et eos debemus lucrifacere, ut supra, et docet Abbas in diet. cap. Quod super his, De voto, nu. 12; Focher in Itinerario, fol. 18, cap. 2, De potestate Papae ad infideles convertendos; Marquardus, parte 2, cap. 2, nu. 3, ubi computat infideles inter oves Christi, creatione, gubernatione et re-

46. Migne, PL, III, 95. 
demptione ex parte Christi, qui dixit Ioan. $10^{47}$, Alias oves habeo quae non sunt de hoc ovili, et illas oportet me adducere et vocem meam audient; $y$ bien es que oigan estos infieles, pues ay exérçito y potençia por donde se pueden excusar, estando V. M. apoderado de las jurisdiçiones y dominios, ut supra. Compruébase esta opinión por el decreto Caritas, § Proximos, De Paenitentia, distinct. $2^{48}$, ibi, et sicut nobis subveniri optaremus, ita eis subvenimus, si facultas non defuerit et proximi nostri credendi sunt omnes homines naturae nostrae participes, ut ibidem. Y dize el cap. Displicet, $33 q^{e}{ }^{e} 4^{49}$, col. 1, ad medium; non tamen ideo, qui diliguntur, malae suae voluntati impune et crudeliter permittendi sunt, sed ubi potestas datur, et a malo prohibendi, et ad bonum sunt cogendi, et ideo Paulus non fuit permissus uti sua pessima voluntate qua pesequebatur Ecclesiam. También el doctor Navarro in Summa confessorum, in primo praecepto Decalogi, cap. 2, nu. 17, pareçe tener esta misma opinión, adonde, pag. 140, hablando de los simples infieles dize, infideles qui non credunt quia non est eis satis notificata fides, licet non peccent non credendo nec ob hoc damnentur, damnabuntur tamen propter alia peccata. Allegat Sanctum Thomam et Caietanum, ubi supra; idem Victoria De Indis, pag. 337, ibi, Damnabuntur tamen propter alia peccata mortalia, ut propter idolatriam, etc. Y que puedan juzgar ydólatras los juezes de V. M., se funda por la ley 5, tt. 24, pda. 7, ibi, "sean libradas por los nuestros juzgadores de los lugares do moraren e non por los viejos dellos", et iterum ibi, "mas si querella oviere dél, demándeselo ante nuestros juzgadores". Pruébase también por lodos los títulos 23 y 25 de la 7 pda. y por el tt. 2, lib. 8 de la Recopilaçión, assí que lo mismo que en los Reynos de Castilla se puede y deve juzgar en estas yslas y nuevo mundo, pues en todo, como está dicho, tiene V. M. su derecho fundado con el glorioso título de la yglesia y sumos pontifíçes y no se pretende hazer agravio ni guerra a los bárbaros, ni quitarles sus haziendas, sino ponerlos in ordine ad spiritualia y encaminarlos en bien suyo dellos y de sus proprias almas.

7. Fortaléçese todo lo dicho con la resoluçión común de los que enseñan y escriven açerca de las causas de la guerra justa, que entre ellas se pone una y es contra los que adoran al demonio, et contra terras in quibus Deus blasphematur per idolatriam. Lucas de Pena, la primera de treze causas que pone es ésta in l. unica C., ut armorum usus inscio principe, lib. $i i^{50}$, fol. 153, col. 2, ante medium. Matheo de Afflictis, la primera de 17 causas de guerra pone ésta, in cap. Domino guerram, in tt. Hic finitur lex Friderici, in usibus Feudorum ${ }^{51}$, fol. mihi 54, col. 1. El gran frai Alonso de Castro entre diez causas que pone, la primera es ésta, in lib. 2 De iusta haereticorum punitione, cap. 14, fol. 12, col. 4, et seq. El doctor Covarruvias puso también esta causa de guerra justa, aunque no se acabó de resolver, in Regula Peccatum, parte 2, § 10, fol. 77 y col. 3 et seq. Pero mejor que nadie se determinó Gregorio López, ubi supra ${ }^{52}$, fol. 82, cols. 3 et 4 et fol. 83, col. 1 et seq., adonde çita dos cánones del Concilio Africano, que se dize Cartaginense, en tiempo del papa Bonifacio primero, en que se mandaron derribar y destruir los ydolos, de manera que no quedase reliquia dellos, por los años de 425 y 426; est videndus Corduba, lib. $1^{\circ}$, q. $^{e} 57$, dub. 9, pag. 499, cum praecedentibus et sequentibus, haunque habla muy largo y prolixo y confuso, que apenas se acaba de resumir y dize ser esta común opinión y más probable de los antiguos y

47. Ioan., c. 10 , vers. 16 .

48. Decreto de Graciano, segunda parte, causa 33, q. 3, De paenitentia, dist 2, c. 14.

49. Ibid., segunda parte, causa 33, q. 4, capág. 38.

50. Tit. 46(47).

51. Libr. 2.

52. Ley 2, tít. 23, Partida 2. 
de algunos modernos, pag. 504, col. 2, in fine. La ley de Partida, ley 2, tt. 23, pda. 2, pone tres causas de guerra justa; y la primera pareçe que quadra bien en quanto dize, por acreçentar al pueblo su fee y para destruir a los que la quisieren contrallar. Y por esto dize Gregorio López, allí, en la glosa final, que quantas causas traen los doctores de guerra justa se pueden resumir en las tres que pone aquella ley, et in specie et in casu isto se puede fundar lo dicho. Por lo que el mismo doctor Covarruvias dize ubi supra tratando de simplicibus infidelibus et idolatris et de peccatoribus in legem naturae, que lo que avía dicho de bello defensivo, vindicativo seu punitivo se limita y entiende, nisi in terris subditis Christiano principi. Assí que en estas yslas, tierras y mares, siendo de V. M. como lo son, puede la Real audiençia y tiene conoçimiento de causas de ydólatras, no embargante que aya de aver moniçión y exhortaçión y publicárseles algunas leyes y ordenanças espeçiales para más justificaçión y para que no pretendan ignorançia los bárbaros, sobre lo qual yo di memorial a esta Real audiençia, no solamente advirtiendo a los infieles no baptizados, sino también a los convertidos, para que conozcan a dios y lo adoren y dexen al demonio y no cometan hurtos y robos ni otros pecados contra la ley de razón natural, y que bivan bien, sin tomarles sus haziendas ni bienes, ni compeliéndolos, ni forçándolos a rrecibir la fee directamente, sino por esta vía justíssima y sancta (pues ay potençia), como dizen los doctores y decretos sanctos arriba dichos; y de otra manera no podrá, con el descuydo que hasta ahora a avido, descargarse la Real conçiençía ni las de sus ministros, si no juzgásemos cada día salteamientos de los campos y caminos y muertes seguras, ydolatrías y ritos mahometanos y gentílicos.

8. Este castigo se puede muy bien hazer, no embargante el capítulo 140 de las Instruçiones ${ }^{53}$ de los decubrimientos, conquistas, poblaçiones y paçificaçiones, en que se manda que los descubridores y pobladores procuren con los infieles todos los medios suaves y possibles para los affiçionar a la fee, y que no comiençen reprehendiéndoles sus viçios ni pecados ni las ydolatrías, ni quitándoles sus ydolos, por que no se escandalizen, según más largamente en el dicho capítulo 140 se contiene, porque de el mismo y de su contestura pareçe disponer quando los bárbaros aun no ovieren dado la sujeçión ni admitido las poblaçiones. Diverso caso es el de que voy tratando, pues demás de aver aquí dado la obediençia y tributado como vassallos, ay exército et facultas adest y no nos tememos de su potençia dellos, ni ay los inconveniente que se tenían al tiempo de la data de las dichas Instruçiones, y pueden ponderarse las palabras del dicho capítulo, ibi (no comiencen), bien se colige ex adiunctis ser éste el verdadero sentido, por el tenor del capítulo siguiente, que es el 141, adonde se manda dar a entender a los infieles el universal poder y suprema jurisdiçión de V. M., y quántos gastos a hecho y haze por su bien spiritual y temporal dellos, y el mucho fruto que dello an reçibido generalmente muchos Reynos y gentes del mundo, quanto más que quando los christianos tuvieren possible y no temen escándalos, pueden los bárbaros ser apremiados a oyr sermones de la fee y a ser predicados y aun compelidos a que bivan bien y dexen los ydolos, como lo dice el Maestro Victoria, De Indis, pag. $364^{54}$, nu. 12 et seq, y dizelo virtualmente el capítulo 27 de la Instruçión de corregidores en el libro de las cédulas, fol. 56, col. 1, ibi, "castiguéis algunos dellos, para que los demás tomen exemplo".

9. Item, si opus fuerit propter hoc bellum suscipere, possumus, como allí lo dice Victoria y lo refiere Gregorio López, dicto fol. 82 in q.e 4, circa ius praedicandi Evangelium; Focher in Itinerario,

53. Las famosas Ordenanzas.

54. Sec. III. 
fol. 5 et seq.; y el cap. 136 de las dichas Instruçiones, de descubrimientos, que no se haga a los infieles más daño del que fuere menester para que la poblaçión no se estorve, y para que los pobladores tengan seguridad, de manera que se mandan hazer las poblaçiones aunque sea a pesar de los bárbaros, lo qual virtualmente está permitido y cometido por la bula de la conçessión de Alexandro sexto y sucessores, et omnes principes et reges terrae, temporales sive civiles, sunt ut vicarii vel legati Papae et Ecclesiae et ministri potestatis papalis. Para lo qual es famosa extravagante y decretal única, De consuetudine, inter communes, fol. 1; incipit Super gentes et regna Romanus pontife $x^{55}$, ibi, necesse habet interdum, ex debito impositae servitutis, suos ad diversas mundi partes, prout necessitates emerserint, destinare legatos qui vices ipsius supplendi errata corrigant, aspera in plana convertant. Bien se funda en la bula de la conçessión, y en esto de las ydolatrías mucho se deve atender el sentimiento que hizo el Redemptor, Matt. $4^{56}$, Vade retro, Satana; scriptum est enim Dominium Deum tuum adorabis et illi soli servies. En estas Yslas Philipinas y cabo del mundo se cumple lo profetizado por Isaías, a quien llaman el quinto evangelista, cap. $41^{57}$, viderunt insulae et timuerunt; extrema terrae obstupuerunt. Y assí es menester el socorro de Dios y de V. M. para proseguir y que se cumpla de propósito lo que el mismo profetizó en el cap. $42^{58}$, Dixit Dominus, et ducam caecos in viam, quam nesciunt, et in semitis, quas ignoraverunt, ambulare eos faciam; ponam tenebras coram eis in lucem, et prava in recta.

10. En esto de la notificaçión de la fe y mandamientos della de creer es que avrán hecho en lo espiritual sus diligençias los religiosos y governadores para que no tengan escusa los infieles, vista la notoriedad de la predicaçión evangélica y que de unas yslas y provinçias a otras an venido y andado inquiriendo los moros y gentiles, y se podría bien dezir lo que Sant Hierónimo dixo, nullam remansisse gentem quae Christi nomen ignoret, ut si non habuerint praedicatores saltim ex vicinis gentibus fidei opinionem habeant. Refiérelo Marquardo, in parte 3, cap. 1, nu. 25, fol. 117 et num. 29, fol. 121, adonde cuenta las partes y tierras donde predicaron los apóstoles, ibi, quod adimpletum est per praedicationes Apostolorum, cum totus orbis hac caecitate duceretur, ut idola colerent, Iudaea excepta; qui primo praedicantes in Hierusalem et inde in finibus Iudaeae et in Samaria, tunc destinati fuerunt in diversas mundi partes, ut Thomas ad Indos superiores et Parthos ultra Pontum; Matthaeus in Aethiopiam; Bartholomaeus ad Indos citeriores, scilicet in Bactrianam, Lycaoniam et Armeniam; Andreas ad Scythas et Sogdianos; Ioannes in Asiam, qui etiam Romam perrexit. Petro autem contigit Italia, maxime Roma, et Pontus, Galatia, Bythinia, et Cappadocia; et Simeoni Aegyptus; Iacobo maiori Hispania. Philippus Apostolus praedicavit triginta annis in Scythia, ut inquit Archiepiscopus Florentinus, parte 1, tit. 6, cap. 2, fol. 125, col. 2, et fuit unus de duodecim Apostolis Christi. Et Paulus de se attestatur, ita dicens, non enim audeo aliquid loqui eorum quae par me non efficit Christus in oboedientiam gentium, verbo et factis in virtute signorum et prodigiorum in Spiritu Sancto, ita ut ab Hierusalem per circuitum usque ad Illyricum repleverim Evangelium Christi. Et subicit usque in Hispaniam. Idemque attestatur Evangelium ad sua tempora esse et fructificare in universo mundo, ut foret verum illud vaticinium, in omnem terram exivit sonus eorum et in fines orbis terrae verba eorum. Singulariter prosequitur Marquardus, ibi; et Alfonsus Guerrerius, in Speculo suo, cap. 31; allegant textum in cap. In novo, distinct. $21^{59}$, ubi littera dicit: Discipuli, iubente Domino, in toto omni orbe terrarum dispersi, Evangelium preadicaverunt. Verdad

55. Extr. comm., lib. 1, De consuetudine, capág. unicum.

56. Vers. 10.

57. Vers. 5.

58. Vers. 16.

59. Decreto de Graciano, primera parte, dist. 21, c. 2. 
es que el mismo Marquardo, parte 3, cap. 1, nu. 29, fol. 121, se pone a disputar an et quomodo Evangelium potuit innotescere in universo, pues en nuestros tiempos se a ydo y aora va intimando a estos yndios y faltan otros muchos por predicar, y en efecto, como el Redemptor lo enseñó y prophetizó Mathei. 24 cap. $24^{60}$ buena señal parecerá cuando se acabe de predicar a todos los hombres el evangelio, que entonces se acabará este siglo, y será el día del Juizio universal, ibi, et praedicabitur hoc Evangelium regni in universo orbe, in testimonium omnibus gentibus, et tunc veniet consummatio, y la autoridad que se trae del Rey David, in omnem terram exivit sonus eorum, se entenderá (exiet). Remítome a Marquardo y a Sant Agustín y Sant Jherónimo y otros Sanctos que alega. No embargante lo dicho, como arriba tengo referido, necessaria oviera sido más diligençia y que los religiosos oviesen aprendido y fuesen aprendiendo todas las lenguas de estas yslas y de la tierra firme de China, y les predicasen a los chinos, pues cada año tenemos aquí tantos navios de huéspedes infieles a quien V. M. tiene mandado que hagamos amistad y regalo para el efeto y prinçipal instituto de la conversión. Justo es que conozcan a dios todas estas naçiones, para que no puedan pretender ignorançia y para que se cumpla lo que el maestro dixo, Jhoanis. $15 \mathrm{cap}^{6}{ }^{61}$, si non venissem, et locutus eis fuissem, peccatum non haberent. Y después que predicó, dize, nunc autem nullam habent excusationem de peccato suo. Y esto sólo es en quanto al pecado de la infidelidad, porque aparte queda lo tocante a las ydolatrías y a los otros pecados contra legem naturae los quales tienen más culpas que los de la sola infidelidad pues desque naçieron los hombres está la ley natural escripta en los coraçones humanos, según está dicho, y lo dice Castro, De lege poenali, lib. $1^{\circ}$, cap. $1^{\circ}$, prope

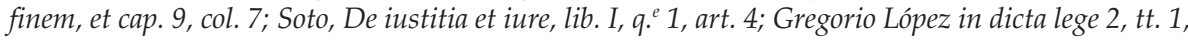
pda. 1, in glossa 1, ibi, sed secundum naturam quam habet homo communem cum angelis, scilicet rationabilitatem, sic diffinitur: Lex naturae vel ius naturale est quidam naturae ratio humanae insita creaturae ad faciendum bonum cavendumque a malo. Y assí se debe aplicar y entender Sant Pablo Ad Rom., 10 cap. $^{62}$, quomodo credent ei quem non audierunt, et quemodo audient sine praedicante?

11. Esta diligençia que yo hago de ordenar algunas espeçialidades para los nuevamente convertidos y baptizados, es neçessaríssima para el fuero secular exterior, no embargante que la reprobaçión de ydolatrías y pecados contra la razón natural se enseña y va enseñando implíçitamente por los religiosos en el primero y los demás mandamientos de la ley de dios, que son hermanos de los de la ley de la naturaleza y conviene mostrarles a los convertidos y a los bárbaros infieles ydólatras también las dichas leyes penales seculares para que bivan bien.

12. Y porque los dichos religiosos afirman la opinión arriba dicha, fundados en aquella authoridad de Sant Pablo, a ellos y a los doctores que la tienen, conviene mucho satisfazerles y responder a su objeçión, porque algunos dellos disputando conmigo afirmaron que aunque vean junto a sí que infieles idolatran y adoran al demonio, no se entrometerán a castigarlos, cosa çierto a mi pareçer muy áspera y escandalosa.

13. Y assí rrespondiendo, salva correctione Sanctae Matris Ecclesiae, digo que en aquellas palabras $1^{a}$ Cor., cap. $5^{63}$, en quanto el Apóstol dize, quid enim mihi de iis, qui foris sunt iudicare?, se entiende desta manera: Que no niega Sant Pablo allí tener poder de juzgar los infieles, ni dize, non possum de iis qui foris sunt iudicare; sed inquit: Quid mihi?, id est, nulla utilitas est eos
60. Vers. 14 .
61. Ibid.
62. Ibid.
63. Vers. 12 
excommunicare, nec aliqua sententia ecclesiastica punire, nam nec mihi oboedient, nec excommunicatio ligat infideles sed solum baptizatos. Y si Sant Pablo quisiera sentir y declarar que la yglesia no puede juzgar a los paganos infieles, porque sean ydólatras y pecantes contra legem naturae, seguirse ya que el papa ni el prínçipe cathólico no podrían castigar a sus subditos ni juzgarlos, que es caso absurdo, teniendo como tiene la yglesia y el derecho proveydo lo contrario, y lo alaba Sant Agustín, según ya tengo dicho, y su decreto está canonizado in cap. 23, Non invenitur ${ }^{64}, q .{ }^{e} 4$, ibi, quis enim non laudat leges ab imperatoribus datas adversus sacrificia paganorum? Estas leyes son las del $t$. Cod. De paganis et sacrificiis et templis eorum ${ }^{65}$, adonde la ley primera pone pena de muerte a los que idolatraren y confiscaçión de bienes, y aun contra los juezes que no los castigaren, ibi, quod si aliquis forte huiusmodi perpetraverint, gladio ultore sternantur, etc. Lo mismo y con mayor exageraçión dize la ley nemo ${ }^{66}$ del mismo título, ibi, absit a saeculo nostro nefandis execrandisque simulacris, etc.; et iterum ibi, apud iudicem publicum reus tanti facinoris legitime accusetur, et convictus proscriptionem omnium bonorum suorum et ultimun supplicium subeat. Y prosigue allí contra los encubridores de los tales sacrifiçios y sacrificadores en la misma ley y en la final también, ley 17, tt. 2, lib. 8 Recopilationis. Y el judío o moro que tuviere acesso con christiana muera por ello, in lege Ne quis Christianam, Cod. De Iudaeis et Sarracenis ${ }^{67}$, in lege 9, tt. 24, pda. 7. La clementina única De Iudaeis et Sairacenis ${ }^{68}$ quita las mezquitas de los moros y manda que los prínçipes christianos destruyan, so pena de excomunión, las dichas mezquitas y castiguen, etc. Las decretales 1 y 2 y otras del mismo título claramente se entrometen a juzgar contra los infieles, y assí entiende Gregorio López aquella authoridad de Sant Pablo, fol. 83, col. 3, alegando algunos derechos, como el capítulo In archiepiscopatu, De raptoribus ${ }^{69}$, adonde el pontífiçe manda castigar a los moros y otros infieles raptores, sodomitas et occisores puerorum, ibi, et si ita fuerit gravis excessus quod mortem vel detruncationem membrorum debeant substinere, vindictam reserves regiae maiestati. $\mathrm{Y}$ en el capitulo Post miserabilem, De usuris ${ }^{70}$, manda el pontífiçe a los prínçipes seculares que hagan castigo contra los infieles usurarios, ibi, Iudaeos ad remittendas Christianis usuras per principes et potestates saeculares compelli praecipimus. La ley 1, tt, 6, lib. 8 de la Recopilaçión, y otros muchos derechos pueden traerse para lo mismo, y este pareçer tuvo y tiene el doctor Navarro açerca de la dicha authoridad de Sant Pablo, in Repetitione cap. ita quorumdam, De Iudaeis et Sarracenis ${ }^{71}$, in 8 notabiliter, nu. 4 et seq. Y por ser magistrales palabras las refiero, quia id intelligendum est quoad excommunicandos infideles directo vel quoad puniendum eos alia poena spirituali vel quaod compellendum eos ad suscipiendam fidem Christianam vel quoad cogendum eos servare leges contrarias suis, quas vere vel falso praetendunt se divinitus accepisse et non sunt naturalibus contrariae; ut mihi video singulariter colligere ex cap. Gaudemus ${ }^{72}$, et cap. finali De divortiis ${ }^{73}$, et cap. finali Qui filli

64. Decreto de Graciano, segunda parte, causa 23, q. 4, c. 41.

65. Lib. 1, tit. 11.

66. Ley 8.

67. Lib. 1, tít. 9, 1. 5.

68. Lib. 5 , tít. 2.

69. Decretales, lib. 5 , tít. 17, c. 4 .

70. Ibid., lib. 5, tít. 19, c. 12.

71. Ibid., lib. 5, tít. 6, c. 6 .

72. Ibid., lib. 4, tít. 19, c. 8 .

73. Ibid., c. 9 . 
sint legitimi"74, nec ideo illa dixit Paulus quod Ecclesia non habeat potestatem quoad hunc casum super infideles. Y çierto es el verdadero sentido de las palabras de Sant Pablo, que aunque se abstuviese de juzgar en lo exterior en causas judiçiales, no por eso se le puede denegar el poder, considerando lo que él mismo dize en el capítulo siguiente I Ad Cor. cap. $6^{75}$, ibi, omnia mihi licent, sed non omnia expediunt. Podría replicárseles a los religiosos, verte folium et videbis; cur non vidistis omnia etiam a tergo scripta? Assí que por entonces y quando dixo Sant Pablo, quid mihi de iis, qui foris sunt indicare? aunque podía, no convenía entrometerse en judicaturas et maxime quia multitudo erat infidelium. Y quando uvo tolerançia en los ritos de ydólatras y de otros infieles, fue en tiempos trabajosos, et diversa sunt tempora pacis et tempora persecutionis, como en otro propósito lo dice Focher in Itinerario, fol. 4, col. 1, y podrá aplicarse lo que el Redemptor dixo, Luc., cap. $22^{76}$, ibi, sed nunc qui habet saculum, tollat similiter et peram; et qui non habet, vendat tunicam suam et emat gladium. Y collígese bien de Sancto Thomás, $2^{a} 2^{a}, q^{e}$ 10, art. 11 et q. ${ }^{e} 12$, art, 2 ad finem, y de Marquardo y Albertino y los demás alegados, a quien me remito. $Y$ dize alli ${ }^{77}$ Sancto Thomás in responsione ad primum estas palabras, ad primum ergo dicendum est quod illo tempore Ecclesia in sua novitate nondum habebat potestatem terrenos principes compescendi, et ideo toleravit infideles, etc. Allí lo declara bien Cayetano, itaque quando adest facultas recte procedi potest, si non timemus potentiam barbarorum. Y pruévolo por lo que el mismo apóstol luego dize dándose más a entender, omnia mihi licent, sed ego sub nullius redigar potestate ${ }^{78}$; de manera que geminadamente afirma quod omnia sibi licebant et sub nullius erat potestate. Geminatio quidem firmitatem denotat et diversitatem iuris ab actu simplici, verbaque geminata significant praecisam intentionem, ut per plura docet Everardus in sua Centuria, in argumento a vi geminationis, pag. mihi 639 et seq.

14. Para este punto viene bien el bordón común, distingue tempora et concordabit scriptura, in cap. 2, Si peccaverit ${ }^{79}, q^{e}{ }^{e}$, ad medium, in lege Apud antiquos, Cod. De furtis ${ }^{80}$, ibi, et sic ex tempore omnibus discretis vetustissima dubitatio nostro foedere conquiescat. Y por esta misma razón se deriva la común doctrina fundada in cap. Quemadmodum ${ }^{81}$, et in cap. Etsi Christus, De iureiurando ${ }^{82}$, y en mill otros derechos, quod dispositiones hominum et legum intelliguntur et interpretantur semper procedere rebus sic stantibus et in eodem statu permanentibus, et omni tempore procedunt, excepto casu de novo supervenienti. Por manera que la tolerançia en unos tiempos es neçessaríssima y en otros tiempos no se puede hazer sin pecado y ofensa de dios y de su justiçia, y viene bien el cap. multi ${ }^{83}, 2, q{ }^{e} 1$, ibi, multi corriguntur, ut Petrus, multi tolerantur, ut Iudas, y esto porque entonçes fue neçessario para que el Redemptor manifestase sus gloriosos juyzios, et in iure nostro multa inducta sunt ex tolerantia superioris, ut refert Avendanius in cap. 1 Correctorum, nu, 29 et nu. 30, fol. 16: y para este propósito se induce bien una çédula de la Ma-

74. Ibid., lib. 4 , tít. 17 , c. 15 .

75. Vers. 12.

76. Vers. 36

77. Migne, PL, III, 112.

78. 1 Cor., c. 6 , vers. 12.

79. Decreto de Graciano, segunda parte, causa 2, q. 1, c. 19.

80. Lib. 6, tít. 2, 1. 21.

81. Decretales, lib. 2, tít. 24, c. 25 .

82. Ibid., c. 26

83. Decreto de Graciano, segunda parte, causa 2, q. 1, c. 18. 
gestad imperial, que sancta gloria aya, la santa Emperatriz, nuestra señora, que está en el libro de las cédulas ${ }^{84}$ de la Nueva España, fol. 78, cap. 26, hablando en casos de las Yndias, ibi, porque no es tiempo de entender en adelgazar tanto la cosa, et tolerata vel permissa ad tempus censentur prohibita post tempus, sicut etiam prohibita ad tempus censentur permissa post tempus, ut late traditur per omnes, ut refert plura Tiraglus De retractu conventionis, §1, glossa 2, nu. 44, cum pluribus sequentibus, pág. 822 et seq. Facit ad hoc bonus textus in cap. 18, De reformatione, sessione 25, in Concilio Tridentino, ibi, sicut publicae expedit legis vinculum quandoque relaxare, ut plenius evenientibus casibus et necessitatibus pro communi utilitate satisfiat; et iterum ibi, quod si urgens iustaque ratio et maior quandoque utilitas postulaverit, etc. $\mathrm{Y}$ aquí viene bien toda la materia de las dispensaçiones, y assí Sant Pablo disimuló su jurisdiçión y poder; las glosas in dicto cap. Gaudemus, et in cap. Post miserabilem ${ }^{85}$, et in cap. Multi $i^{86}$, verbo iudicare, y todos los doctores allí entienden aquella palabra de Sant Pablo que iudicare se entienda quantum ad excommunicationem, sed tamen quod corporaliter infideles possunt puniri y el derecho está lleno de este sentido, et leges, cánones et dispositiones temperantur quotidie propter bonum publicum, propter periculum, propter pacem, propter scandalum evitandum et ex eliqua alia iusta excusatione, como muy largamente lo enseña Alciato en todo el libro primero De verborum significatone, al qual me remito, y assí el mismo Redemptor quiso pagar tributo, ut Matt., cap. $17^{87}$, ibi, ut autem non scandalizemus.

15. Aviendo Gregorio López con mucha doctrina largamente sustentado la potençia de la yglesia y su jurisdiçión contra los ydólatras et alios peccantes contra legem et rationabilitatem naturae, queriendo resolver toda la materia de la dicha su Repetiçión en nueve conclusiones ${ }^{88}$, en la sexta se queda confuso y atajado vir quidem alioqui doctissimus, y dize que no osa determinarse y se rinde por una palabra del evangelio, Matt., cap. $10^{89}$, adonde dixo el Señor, ecce ego mitto vos sicut oves in medio luporum, y en efecto dize, ex hoc non auderem ad praesens consulere quod in acquisitione istorum infidelium illa doctrina utatur, scilicet punire idolatras, si a falsorum deorum cultu non desistant et unum non recognoscant, seu contra infideles alias peccantes in lege naturae, si moniti se non corripiant. A la qual duda de Gregorio López está muy fáçil la respuesta, considerando lo dicho, y lo que en unos tiempos se a de tolerar, y en otros executar, ut supra; y aquella palabra, ecce mitto vos sicut oves in medio luporum, se entiende conforme al tiempo de la persecución, que avía entonçes muchedumbre de infieles ydólatras, et rebus sic stantibus, non autem in casibus de novo supervenientibus, como en estos tiempos, donde ya las ovejas y corderos se volvieron leones y no temen a los lobos et facultas adest. Y bien se lo advirtió todo en el mismo capítulo 17 Jesuchristo quando luego les dixo, estote ergo prudentes sicut serpentes, y la prudencia es la mayor virtud de todas las virtudes morales, y tiene tres actos y potençias señaladíssimas, que son consulere, iudicare et imperare, memoria de lo passado, templança en lo presente, providençia en lo porvenir; collígese de Sancto Thomás, y refiérelo doctíssimamente el maestro Soto, lib. 3, De iustitia et iure, q. ${ }^{e}$ 2, art. 8, pág. 207. Et profecto praeter rationem naturalem aliarum intellectualium virtutum, etiamsi consideretur qua parte moralis est, prudentia pretiosior est aliis, notat Corduba, licet prolixe, in lib, II, fol. 55. Y pues se concedió a los apóstoles este grande indulto de

84. Vasco de PugA, Provisiones, cédulas, instrucciones de Su Magestad, México, 1563.

85. Decretales, lib. 5 , tít. 19 , c. 12.

86. Decreto de Graciano, segunda parte, causa 2, q. 1, c. 18.

87. Vers. 27.

88. Ley 2, tít. 23, Partida 2.

89. Vers. 16. 
la prudençia, entiéndese con sus calidades que tiene impliçitas, de consultar, imperar, y juzgar, dize Oldendorpio in tractatu De iure naturali, nu. 8, in vol. 7 Tractatuum diversorum doctorum, fol. 4, semper igitur memento, cum audis haec verba, lex, ius, iustitia, iurisprudentia erigendam esse cogitationem ad excelsam quandam soli homini a Deo donatam virtutem. Y no ignorava Sant Pablo su poder, aunque dexó de castigar y juzgar infieles, pues geminadamente dixo, omnia mihi licent, ut supra, y en efecto no se quiso ocupar en judicaturas del fuero exterior, sino en la predicaçión, quia sancta Ecclesia Christi consulit potius animabus quam corporibus, in cap. Cum infirmitas, ubi glossa in verbo multo, De paenitentiis et remissionibus ${ }^{90}$; et Evangelium tractat de aeterna vita et de iustitia spiritus, ut per Oldendorpium, ubi supra, fol. 5, nu. 15, vers, rursus; bien lo enseña el cathechismo, pag. mihi 578, declarando aquella palabra de Christo, Jhoanis, 18 cap. ${ }^{91}$, regnum meum non est de hoc mundo, que se entiende quia mundus conditus et interiturus est et regnum Christi aeternum est et non periturum nec interiturum, de manera que el Redemptor ni Sant Pablo no se ocuparon en judicaturas de este mundo, sino en edificar almas para lo eterno.

16. Y con esto mismo se satisfaze a la authoridad que los dichos religiosos de Sant Agustín alegan, Luc., 12 cap. ${ }^{92}$, ibi, homo, quis me constituis iudicem, aut divisorem supra vos?, porque aunque dize su divina Magestad, data est mihi onmis potestas in caelo et terra, Matt, último ${ }^{93}$, no quiso hazer petiçiones de herençias, ni negoçios seculares, ni usar más que su predicaçión y dar exemplos y dechados de vida sanctíssima y espiritualíssima, y quien otra cosa dixere no lo sustentara ni sé yo como se salvara.

17. Por su proprio pareçer de los dichos religiosos se confunde su opinión juntando lo que yo tengo fundado, porque refieren la doctrina de Sant Augustín in Sermone 6 De verbis Domini, adonde aviendo quien se ofreçia a derribar y quebrantar los ydolos de los gentiles y paganos, dixo, ne faciatis ista, quando in potestate non est, ut faciatis illa; pravorum est et furiosorum et circumcellionum, ubi potestatem non habent saevire et velle mori. Son palabras que se retuerçen contra los que las alegan evidentemente, pues que concuerdan con lo que yo tengo alegado del mismo Sant Augustín, su padre, in cap. 23, Non invenitur ${ }^{4}, q^{e}{ }^{e} 4$, ibi, quis vestrum non laudat leges ab imperatoribus datas adversus sacrificia paganorum?. Y assí con esta authoridad del Sermón 6, De verbis Domini, vienen las doctrinas de los otros sanctos y doctores, que dicen quod ubi adest potestas, puniuntur sacrificia paganorum et ritus infidelium; quando autem potestas non adest, tolerantur, ut supra.

18. A otra objeçión en que se fundan los dichos padres, me resta dar satisfacción, aunque de suyo se está dada; y es en quanto dizen que assí como directamente no pueden ser compelidos los infieles a reçibir la fee, tampoco pueden per indirectum, quebrantándoles y derribándoles los ydolos, ni de otra manera, y dizen que sería absurda cosa apremiarlos per indirectum. Están engañados y convençidos por lo que su proprio padre Sant Augustín ${ }^{95}$ dize en la Homilía 7, por fundamentos muy cathólicos y razonables, y que aunque la ley es de

90. Decretales, lib. 5 , tít. 38 , c. 13.

91. Vers. 36 .

92. Vers. 14.

93. C. 28 , vers. 19.

94. C. 23 , q. 4 , c. 41.

95. Aquí el texto revela que esta segunda carta tiene como motivo contestar las alegaciones sobre la evangelización realizadas por los agustinos -la primera orden religiosa en establecerse en el archipiélago-, pues Melchor de Ávalos especifica "están engañados y convençidos por lo que su proprio padre Sant Augustín [...]". 
amor, pueden imponérseles grandes tributos y derribando los ídolos y estorvando los delictos y pecados, y haziéndolos bivir políticamente, todo esto encaminado y endereçado para que se apresten a reçibir la fee, et ad baptismum festinent. Y aunque sea verdad, por el capítulo sicut, De ludaeis et Sarracenis ${ }^{96}$ et in cap. De ludaeis, distincit. $45^{97}$, ubi Summus Pontiffex prohibet exigi ab eis servitia coacta, ubi doctores notant, et in cap. Iam nunc, 28, q. $1^{98}$ docet Marquardus, parte 1, cap. 6, nums. 6 et 7, in vers, quibus tamen non obstantibus, ubi limitant dictum capitulum sicut non habere locum, quando talis exactio fieret, ut per hoc infideles inducerentur ad fidem et compellerentur mediantibus exactionibus festinare ad rectitudinem Christi; licet enim quis in vitiis non cogatur ad fidem, ut in dicto cap. sicut, id tamen intelligitur de coactione, quae fit per violentiam illatam personae vel per ablationem rerum suarum; coactio autem per impositiones collectarum vel tributorum permissa est, per textum in canone Iam vero ${ }^{99}$, et ibi doctores notant $23, q .6$, ibi, tanto pensionis onere gravandus est, ut ipsa exactionis suae poena compellantur ad rectitudinem festinare, y alude bien el capítulo final 23, q. $4^{100}$, ibi, non ut odium exerceatur, sed ut pravitas corrigatur. Es decreto sacado de Sant Augustin ${ }^{101}$, quia mali sunt prohibendi a malo, et cogendi ad bonum. Est sic vindicta est inferenda zelo iustitiae et non amore ipsius vindictae, ut ibi Gratianus prosequitur; idem firmat et fundat Ioannes de Anania in dict. cap. sicut, nu. 8 et 9, super glossam 1; et pulchre probat Marquardus, et prosequitur ubi supra; et in parte 3, cap. 2, nu. 8. Focher, fol. 14, cols. 1 et 2, ubi allegat idem tenentes praepositum et abbatem, in dict. cap. De ludaeis, distinct. 45 . De ver es aquel texto adonde el Conçilio llamó religiossísimo al Rey Sisebuto de España, aunque forçó a los judíos que reçibiesen por fuerça el baptismo, lo qual ponderan muchos doctores y Cayetano, Super Sanctum Thomam, $2^{a} 2^{a}, q .10$, art. 8, adonde dize refiriendo a Escoto entre otras cosas que es menos mal compeler los infieles a la fee que no sería consentir un príncipe christiano estarse perdidos en sus ydolatrías y leyes ilíçitas. Mucho pudiera detenerme en fundar mi opinión, pero basta aquel capítulo Iam vero 23, q. 6, y más lo que el Redemptor dixo, Jhoanis, 4 cap. ${ }^{102}$, hablando con la Samaritana, nos adoramus quod scimus et vos adoratis quod nescitis, y estando çertificadíssimos los christianos de esto, y conoscendo los ydólatras andar errados, mala quenta daríamos a dios si no remediásemos a los perdidos que adoran lo que no saben.

19. Assí que concluyo podérseles imponer a los infieles tributos mayores que a los fieles para que se apresten a creer lo bueno, y servirá esta determinaçión para deçidir la segunda duda que los religiosos hazen açerca de los tributos en estas yslas.

20. Espeçialmente que los dichos tributos son para los gastos tan grandes como V. M. haze y a hecho de sus thesoros y hazienda Real para sustentar los predicadores y religiosos y a los ayudantes, que somos quantos acá passamos, presidente y oydores y governadores y juezes y soldados, que no a de militar nadie a su propia costa, como Sant Pablo dice I Ad Cor., cap. $9^{103}$, ibi, quis militat suis stipendiis umquam? Quis plantat vineam et de fructu eius non edit? Quis pascit gregem, et de lacte eius non manducat? Sobre lo qual hablaré más largo en otro propósito,

96. Decretales, lib. 5, tít. 6, c. 9.

97. Decreto de Graciano, primera parte, dist. 45 , c. 5.

98. Ibid., c. 8.

99. Ibid., causa 26, q. 6, c. 4.

100. C. 54.

101. Ad Donatum presbyterum, epist. 204.

102. Vers. 22.

103. Vers. 7. 
que es açerca de las cosas que los conquistadores tomaron de comer para sus forçosas neçessidades y se valieron de los naturales de estas yslas, en que padeçieron y sus herederos han padeçido mucha vexación del obispo y religiosos, compeliendo a pagar a los más abonados y mejor parados, por los que no lo son, y se an puesto en denegarles confessión y absoluçión.

21. Con lo dicho queda resolutamente muy bien fundado que V. M. puede y su Real audiençia y ministros podemos juzgar, punir, y castigar los infieles, ydólatras y peccantes adversus legem rationis naturalis, aunque vivan apartados de los nuevamente baptizados y aunque no les den escándalo los infieles, y bivan en otras yslas, pues siendo vasallos de tan cathólico y religiosíssimo prínçipe, no se les pueden ni deven consentir ydolatrías, quia facultas adest; y biva, biva V. M., por quien pareçe aver dicho Sant Pablo Ad Rom., cap. $13^{104}$, a este propósito, non enim sine causa gladium portat; minister enim Dei est, vindex in iram ei, qui malum agit. $Y$ pues Sant Pablo llama a V. M. vengador de las ynjurias de dios y mantenedor de la fee, justo es que no consienta ydólatras y les digamos, nos adoramus quod scimus et vos adoratis quod nescitis, Jhoanis. 4 cap. Y de esta manera se deve entender el negoçio y assí lo entiendo yo, porque Jesuchristo no nos diga lo que dixo a sus persecutores, erratis nescientes scripturas nec virtutem Dei, Mathei, 22 cap $^{105}$.

22. Açerca de los chinos que llaman sangleyes, mercaderes que de la China vienen a contratar y an venido este año catorce o más navios, sepa V. M. que aquí juzgamos sus contratos y delitos con moderaçión y por las leyes Reales, pero aunque se sabe que son ydólatras o se presume llanamente que lo son, no nos entrometemos en el castigo desto, por ser huéspedes y por el regalo que V. M. manda usar con ellos, y algunos se convierten y baptizan. Justo será ymbiar instruçión y assí lo suplico.

—. En Manila, de las Yslas Philippinas, 20 de Junio, día de Corpus Christi, año de 1585.

Sacra Cesárea Magestad Real,

besa los pies de V. M, su más humilde criado

$$
\text { Li. }{ }^{\text {ado }} \text { M. }{ }^{\text {or }} \mathrm{d}^{\prime} \text { Ávalos }
$$

[rúbrica]

104. Vers. 4.

105. Vers. 29. 